\title{
中国禅宗寺院で詠まれた題詩と「境致」の関係
}

\section{The relation between poetry made at Zen Buddhist temples in China and the Kyochi}

\author{
平出美玲 \\ HIRAIDE Mirei
}

\author{
Key Words : 1 . 禅宗寺院 2. 境致 3 . 十境 \\ 1. Zen Buddhist temples 2. poetry of Zen Buddhism 3. kyochi
}

\section{摘要}

日本の禅宗寺院で伝統的に選定が行われてきた「境致」 や、それに伴って詠まれた「十境詩」は、南宋五山制度 を導入した時に中国禅宗文化の一つとして日本でも知ら れるようになったと考えられている。これまでに成され た「境致」に関する先行研究でも、中国禅宗寺院の影響 を受けて日本でも「境致」選定や「十境詩」作成が行わ れるようになったという解釈がされている。そこで本稿 では中国で編集された地方誌『中國仏寺志彙刊』を史料 とし、中国に於ける「境致」選定や「十境詩」の実態を 調査・整理した。それにより、これまで漠然と中国禅宗 郝完と考えられてきた「境致」選定の起源を、より明確 にする事ができると考えた。その結果、日本で編纂され た、『扶桑五山記』や『和漢禅刹次第』に記載されてい る「中国禅宗寺院の境致」とみなされている題が、中国 で編纂された『中國佛寺志彙刊』の内容とは一致してい ないことが明らかになった。

\section{Abstract}

The Zen sect was introduced in Japan at the end of the twelfth century, and spread systematically from epoch Kamakura (1185-1333). The authority of this epoch, who had just taken its power, introduces a Chinese administrative system to control Zen Buddhist temples, that is about the Five Mountain
System "Gozan-seido" for the object to use politically this sect. The introduction of the system from China brought consequently a Zen culture developed in the Chinese Zen Buddhist temples around the Five Mountains temples of the Southern Song Dynasty (1127-1279), and it gave great influence in the development of all areas of Japanese culture at later periods. The famous literature of Five Mountain System "Gozan-bungaku" is the domain in specialty of a Chinese culture that developed and flourished all along the Kamakura and Muromachi periods. In these works, which were written by monks, many poems were inserted among which we have poems "Jikkyo-shi'. We thought long time as the poesy of "Jikkyo-sh" is a genre which was introduced in parallel with other cultural areas of China, and we have not enough studies yet to certify that definition. To confirm the definition, we study the text published in China in the time of the Ming (1368-1644) and Qing (1616-1912), about the history of Buddhist temples in China which is “中國仏寺志彙刊” ( the History of Buddhist temples in China ). We can consider that the text is valid to see the propagation of the concept "kyochi" to the community of Zen sect in China of the time of the apogee of the Five Mountains 
temples, because the definition of previous studies on the same subject was based also about the contents of this text.

In this study, I collected examples of poetry in the form of decade "Jikkyo-shi" mainly in the texts on five major temples that these are Jing shan si, Ling yin si, Tian tong si, Jing ci si, and A Yu wang shan si. Then I classify the poems and analyze several ways to determine the historical meaning of the concept "kyochi" in Zen culture whose construction of the Japanese garden the next few times is strongly influenced. And I found, en effect, that there are some differences between the texts written in Japan and in China.

\section{1.はじめに}

12 世紀末に栄西が日本に伝えた禅宗が、日本で本格的 に広まったのは鎌倉時代以降である。時の鎌倉幕府は禅 宗を公の宗教として利用するために、南宋の官寺制度を 導入し五山十刹を制定した。同時に取り入れられた中国 禅宗寺院文化は、その後の日本文化に多大な影響を与え ることとなった。その中で、各郝完において禅僧によっ て選定される「境致」や、それに対して詠まれた「十境 詩」についても、五山制度と共に日本にもたらされた中 国禅宗文化の一つであると考えられてきた。禅宗封完の 境致についての先行研究は複数存在するが、「境致」に ついて言及している最初の論考は、1934 年に出版された 外山英策の『室町時代庭園史』である。この研究は室町 時代の庭園について、論文中で一貫して「境致」や「十 境」の考察を行い、この時代の庭園文化における「境 致」や「十境」の重要性を示唆している。しかし、外 山英策の研究は日本の事例だけを対象としているた めに、その手本となったとされる中国での事例につい ての考察が行われていない。そこで主だった先行研究 の中で、特に中国禅宗封院の境致について言及している 田島柏堂、関口欣也、蔡敦達の三氏の論文を挙げ、以下 にその内容と本研究と関連寸る問題点についてまとめた。

田島柏堂は「「天童山十境」と禅語散策 - 「拜登」・ 「警策」考 -」の中で、永平寺十四世建撕（1415-1474） が記した道元の伝記『建撕記』の中に記載されている「天
童山十境」（異本有り）について、建撕が何を拠り所に して收録したのか不明であるとして、その究明を試みて いる。参考としているのは『五山十刹図』（金沢市大乗 寺所蔵）の「天童山景徳寺伽藍配置図」と『天童寺志』 （『中國佛寺志』）で、『建撕記』に記載されている十 境の題を各本の文章と照らし合わせ、十境の所在地を明 確にする試みを行っている。この十境の 10 題のうち、「登 閣」が『天童寺志』『天童寺續志』に見えないことを明 らかにし、「登閣というのは、何々閣という楼閣（高層 の建築物）に登って、外を眺めた絶景を称し、閣は千仏 閣のことを指しているように推考される゙」と述べている。 田島はさらに「十境」の語彙について、「「十境」とい う題名でまとまった記録は、『寺志』、『續志』あるい は中国の語録などを検索するも、宋・元・明の間には見

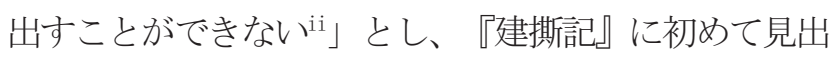
されると述べている。そして、「「十境」もおそらく禅 師が在宋中または帰国後、選定命名して何かに書き留め てあったのを、建撕が採録したものと推測される 述べている。ここでわかることは、田島柏堂が「十境」 という題名でまとまった記録が中国語の文献には見出さ れないと明記していることである。これは本論文でも主 題として検証した事柄である。

また関口欣也は論文「中国江南の大禅院と南宋五山」 で、記録に残っている中国禅宗封院の境致の所在とその 特質について言及している。この中で関口は、「『大宋 国諸寺次位』をみると、境致はその寺の建築や自然環境 の勝地および霊跡などからなり、江南の大禅院では自然 的、人工的、宗教的、歴史的環境の総合美が尊ばれてい たことが知られ、山を控えた占地を反映して前山や後山 を境地に数え、境致と江南の山水との深い関係を示して いる る。また、境致の概念が何時頃生じたのかについては、 成熟過程はまだ明らかではないとしながらも、唐代に遡 るとしている。また、北宋時代の作例として「舒亶が天 童寺を詠んだ詩”の題を 10 種挙げ、「十境」と述べて いる。しかし、この題詩は舒亶の著作『乾道四明図経』 において「天童十題」の名で記載されているものである。 そのため、この 10 題の詩が「十境詩」として定義できる かについては疑問が残る。また「中世五山伽藍の源流と 展開」という論文では、境致について「五山をはじめと 
する禅宗寺院では禅宗の自然観にもとづき、周囲の自然 環境を尊重して、これと伽藍との総合的な景観美を境致 という言葉で表現し、大伽藍から小禅院まで、寺の内外 の景観を構成する山や池および諸堂を境致に数えた。そ して境致は漢詩で文学的に理想化され、環境の美化をい っそう増進した ${ }^{\mathrm{vi}} 」 と$ 説明し、日本におけるそれらの源 流は「南宋から元の五山を筆頭とした大禅宗封完にある」 と述べている。また『扶桑五山記』の「南宋国諸寺次位」 をもとに「境致はその寺の建築や自然環境の勝および霊 跡などからなり、江南大禅院では自然的、人工的、宗教 的、歴史的環境の総合美が尊ばれていたことが知られ、 山をひかえた占地を反映して前山や後山を境致に数え、 江南の山水と境致の深い関係を示している。そして北宋 ころから適当な数の境致（多くは十）を選んで詩に詠わ れ、景観美が詩で文学的に理想化された」と述べている。 また、境致の対象となるものは、郝完中心部の建築群よ りも、寺ごとに変化に富む周辺の自然景観とそれを生か した亭などであるとしている。そして「境致の概念は「十 景」などよりきめがこまかく、日本の禅院の環境形成に きわめて大きな影響をおよぼした ${ }^{\mathrm{vii}} 」 と$ 説明している。 このように関口は、境致の概念が宋代の江南禅宗封完か ら日本に伝わったとしている。しかし本論文で検証して いるように、その根拠となる文献『扶桑五山記』に記載 されている南宋五山各郝完の境致は、中国で編纂された 文献『中國佛寺志』の中には記載されていなかった。そ のため今後のさらなる検証が必要であると考える。

蔡敦達は「日本の禅院における中国的要素の摂取 : 十 境を中心として」で、境致選定が中国でいら頃はじまっ たのか、そして日本に取り入れられてからどのように発 展したかを考察している。そして南宋五山を中心とする 中国禅宗郝完で行われていた境致の選定は、当時の文人 がその邸宅や別荘の庭園に対して 10 の景物を選んで詩 に詠むという慣習に影響を受けて発達したものであり、 これら「十詠」「十題」といら詩の形式が禅宗封院にお いて「十境」へと発展したと述べている。その根拠とし て日本人入元僧の別源円旨（1294-1364）の『南遊集』に 収録されている「和雲外和尚天童十境韻」を挙げ、この 偈頌が雲外雲岫の偈頌の和韻詩であることから、天童寺 十境は雲外雲岫によって選定されたものであろうと述べ ている。さらに、この天童寺十境の 10 題は全て『扶桑五
山記』の境致の記載の中に含まれていることから「十境 の選定は南宋以降、五山をはじめとする中国の禅院で行 われていたことがわかる この結論を裏付けるための例として、舒亶（1041-1103） の『乾道四明図経』に載る「天童十題」を挙げ、「天童 十題」のうちの 5 題が先の「天童十境」と重なることを 指摘し、「文人・禅僧を問わず、同じ主題を詩・偈に書 いたことは、直接ではなくても両者の間に交流のあった ことが窥われる。(中略) 禅僧による全員の十境選定は、 こうして文人から影響を受け、また、かれらとの交流を 通じて作り出されたものと思われる かし、先の関口欣也の論文の項でも述べたように、「十 題」と「十境」を単純に同じものと見做してもよいかと いう疑問が残る。詠、題、景、境の違いについて蔡敦達 は、同じ 10 種の題詩に対して史料毎に詠が使われていた り景が使われていたりして、一定ではないことから「「十 詠」「十題」が「十景」に変化するプロセスはさらに「十 境」へとつながるもので、「十境」は「十詠」「十題」 を踏襲したものと考えられるメと説明している。また当 時流行していた「八景図」や「八景詩」も十境における景 観選定に影響を及ぼしたと述べている。そして中国の禅 院で行われていた境致選定の根拠となる史料として、『扶 桑五山記』及び別源円旨の『南遊集』が挙げられている。 しかし、これらの史料はどちらも日本人によって書かれ た日本の文献である。そうであるならば、中国における 事柄についての根拠を求める時に、日本で書かれた文献 史料と中国で書かれた文献史料との内容に異なりが有る 場合、中国の文献の内容を考慮に入れないで結論を出す ことはできない。また、舒亶の「天童十題」についても、 関口欣也の項で述べた通り、「十題」と「十境」を同じ ものと見做してよいのかという検証を行う必要があると 考えた。

境致そのものを論じている最初の論文は、玉村竹二の 「禅院の境致」である。ここでは主に、日本における「境 致」選定についての考察が行われている。中国禅宗寺院 について言及された箇所では、日本同様に数多くの十境 が設定されていたらしいと述べた上で、その根拠として 『和漢禅刹次第』や『扶桑五山記』と共に「『天童寺志』 をはじめ、中国の各寺志類にも記されてみる所である と、『中國佛寺志』の記述を挙げている。 
このように、先行研究の中で度々言及されている「中 国禅宗寺院の境致」について、実際に中国の文献を調べ ることで、その有無も含めて「境致」とは如何なるもの であったのかを明らかにしたいと考えた。史料とする文 献は、中国で明代から清代にかけて数多く編纂された地 方志の一種である『中國佛寺志彙刊』を使用した。この 文献は、上述したように田島柏堂や玉村竹二が、中国禅 宗封完における「境致」選定の有無の根拠として言及し ていることからも、史料として有効であると考える。『中 國佛寺志彙刊』の中で、南宋五山封完についての文献は 『径山志』、『武林靈隠寺志』、『雲林寺志』、『天童 寺志』、『勅建浄慈寺志』、『明州阿育王山志』、『明 州阿育王山續志』の 7 冊である。本論文では、主にこれ ら 5 つの各捖で詠まれ、編纂された詩偈の中からひと まとまりになった題詩を上述の文献から探し出し、その 種類を詩形や題の違いにより分類した。さらに詩の題が、 『扶桑五山記』や『和漢禅刹次第』といった日本の文献 における記述とどの程度共通しているかを調べた。

\section{2. 南宋五山寺院において詠まれた題詩}

\section{（1）萬寿寺}

興聖萬寿禅寺は径山寺の主寺とされている。『径山志』 巻九に「偈詠」、巻十に「名什」の章が設けられていた が、これらの章には一定数のまとまった題詩は収録され ていなかった。ただし『扶桑五山記』の萬寿寺の項に記 載されている 20 種類の題（「清涼法海 (山門)」「龍井」

「天下徑山」「五䯽峯」「龍淵室」「淨髪閣」「不動巌」 「不動軒」「凌霄閣」「含暉亭」「御愛峯」「掲石繁」

「楞伽室」「流止亭」「福地」「靈雞塚」「鉢孟峯」「碁 盤石」「萬年正續完」）のうち、5 種類の題を冠した詩 が、それぞれ単独で収録されていた。巻九の「偈詠」に は、原肇の「掲石嚴」（七言律詩）、龍大淵の「含暉亭」 「凌霄閣」（七言律詩）と、超宗の「掲石」「盤陀石」 (七言絶句) が収録されていた。また巻十の「名什」に は、范至能の「凌霄庵」（五言排律）、徐禁弁の「掲石 嚴」（五言絶句）、黄汝亨の「題靈雞塚」「題掲石嚴」

(五言絶句) が収録されていた。「偈詠」と「名什」の 両章合わせると、「掲石 (巌)」4 首、「凌霄 (閣・庵)」 2 首、「含暉亭」 1 首、「盤陀石」 1 首、「靈雞塚」 1 首 で、「掲石」が最も多い。これらの詩を分類したものが
以下の表である。右に作者名と詩の形態を記載した。

『径山志』に収録されていた「『扶桑五山記』記載の題 を冠する題詩の数と形態

\begin{tabular}{|c|c|c|c|c|c|}
\hline $\begin{array}{l}\text { 原肇 } \\
\text { 七言律 } \\
\text { 詩 }\end{array}$ & 掲石嚴 & & & & \\
\hline $\begin{array}{l}\text { 龍大淵 } \\
\text { 七言律 } \\
\text { 詩 }\end{array}$ & & 凌霄閣 & 含暉亭 & & \\
\hline $\begin{array}{l}\text { 超宗 } \\
\text { 七言絶 } \\
\text { 句 }\end{array}$ & 掲石 & & & 盤陀石 & \\
\hline $\begin{array}{l}\text { 范至能 } \\
\text { 五言排 } \\
\text { 律 }\end{array}$ & & 凌霄庵 & & & \\
\hline $\begin{array}{l}\text { 徐柇弁 } \\
\text { 五言絶 } \\
\text { 句 }\end{array}$ & 掲石巖 & & & & \\
\hline \multirow[t]{2}{*}{$\begin{array}{l}\text { 黄汝亨 } \\
\text { 五言絶 } \\
\text { 句 }\end{array}$} & $\begin{array}{l}\text { 題掲石 } \\
\text { 巖 }\end{array}$ & & & & $\begin{array}{l}\text { 題靈雞 } \\
\text { 塚 }\end{array}$ \\
\hline & 4 首 & 2 首 & 1 首 & 1 首 & 1 首 \\
\hline
\end{tabular}

以上の 5 題の詩を形態から分類すると、七言律詩が 3 題、七言絶句が 2 題、五言排律が 1 題、五言絶句が 2 題 (そのうちの 1 題は重複) である。このことから、これ らの詩は、題が『扶桑五山記』に収録されているうちの 5 題ではあっても、同種類ひとまとまりの題詩とは考え られない。

また「偈詠」の章内に、祖銘によって詠まれた 5 種類 の峰に対する題詩がまとまって収録されていた。いずれ も五言古詩 (六句) で「堆珠峰」「大人峰」「鵬博峰」 「宴坐峰」「朝陽峰」の 5 題であるが、これらの 5 題は 『扶桑五山記』には記載されていない。

\section{（2）霊隐寺}

『霊隠寺志』には 7 首のまとまった題詩が収録されて おり、その題詩がもともと 10 首あったうちの 7 首を収録 
している由が記載されていた。しかしそれ以外に「境致」 や「十境」の記載はなかった。この 7 首は『霊隠寺志』 巻八「詩詠」の五言古詩を集めたなかに収録されていた。 それは梅訽（訽知和尚）が詠んだもので、「有靈隠寺詩 十首勒石冷泉亭上今在七首 ${ }^{x i 1} 」$ 記載されているように、 もともと 10 首の詩が石に刻まれていたが現在はそのう ちの 7 首が残っている。詩は八句の古詩で「本寺（霊隠 寺）」「冷泉亭」「飛来峰」「曲水亭」「龍泓洞」「蓮 華石」「猿呼洞」の 7 題である。この 7 題を『扶桑五山 記』に記載されている題と比較すると、『扶桑五山記』 記載されているのは「蜚来峯」「直指堂」「冷泉亭」「猿 呼洞」「石蓮峯」「北高峰」「合澗橋」「壑雷亭」「鷲 嶺」「九里松徑」「蓮峯堂」「梅檀林」の 12 題であった。 この題の中で「霊隠寺詩十首」中の 7 首に含まれている のは「冷泉亭」「飛来峰」「猿呼洞」の3 首だけであっ た。

『霊隠寺志』の 7 首と『扶桑五山記』記載の題の比較

\begin{tabular}{|l|l|}
\hline $\begin{array}{l}\text { 『霊隠寺志』10 首のうちの } \\
7 \text { 首 }\end{array}$ & 『扶桑五山記』 \\
\hline 「本寺 (霊隠寺) 」「曲水 & 「直指堂」「石蓮峯」「北 \\
亭」「龍泓洞」「蓮華石」 & $\begin{array}{l}\text { 高峰」「合澗橋」「壑雷亭」 } \\
\text { 「鷲嶺」「九里松徑」「蓮 } \\
\\
\text { 峯堂」「梅檀林」 }\end{array}$ \\
\hline 「冷泉亭」 & 「冷泉亭」 \\
\hline 「飛来峰」 & 「蜚来峯」 \\
\hline 「猿呼洞」 & 「猿呼洞」 \\
\hline
\end{tabular}

『霊隠寺志』の題詩は、もともと 10 首あったうちの 7 首なので、単純に『扶桑五山記』の 12 題と比較すること は難しいが、それでも 7 題のうちの 3 題しか共通しない というのは決して多いとは言えない。霊隠寺周辺の景勝 地の中でも特に「冷泉亭」「飛来峰」「猿呼洞」は現代 に至るまで著名であることから、これらの題詩が詠まれ た当時から広く知られた名勝地であったことが、詩に詠 まれた理由とも考えられる。

『霊隠寺志』巻八は、「詩詠」を年代別ではなく、詩 の形態別に収録した巻である。ここには五言古詩 31 首
（このうちに上記の 7 首を含む）、七言古詩 8 首、五言 律詩 46 首、七言律詩 54 首、五言絶句 18 首、七言絶句 38 首、五言排律 8 首がそれぞれ収録されていた。『霊隠 寺志』に収録されていた題詩の中から上述の『扶桑五山 記』に記載された 12 題と同じ題の詩を抜き出すと、いず れの形態にも『扶桑五山記』に記載されている題の詩が 含まれていたが、その種類は 12 題のうちの 6 題だけであ ることがわかった。それ以外に「霊隠寺」の題詩が五言 絶句以外の全ての形態で詠まれていた。それぞれの題を 形態ごとにまとめると以下のようになった。

詩の形態で分類した『霊隠寺志』記載の題詩

\begin{tabular}{|c|c|c|c|c|c|c|}
\hline $\begin{array}{l}\text { 五言古 } \\
\text { 詩 }\end{array}$ & $\begin{array}{l}\text { 七言 } \\
\text { 古詩 }\end{array}$ & $\begin{array}{l}\text { 五言 } \\
\text { 律詩 }\end{array}$ & $\begin{array}{l}\text { 七言 } \\
\text { 律詩 }\end{array}$ & $\begin{array}{l}\text { 五言絶 } \\
\text { 句 }\end{array}$ & $\begin{array}{l}\text { 七言絶 } \\
\text { 句 }\end{array}$ & $\begin{array}{l}\text { 五言排 } \\
\text { 律 }\end{array}$ \\
\hline $\begin{array}{l}\text { 飛来峰 } \\
\left(\begin{array}{l}4 \\
\text { 首) }\end{array}\right.\end{array}$ & & $\begin{array}{l}\text { 飛来 } \\
\text { 峰 } \\
(4 \\
\text { (首) }\end{array}$ & $\begin{array}{l}\text { 飛来 } \\
\text { 峰 } \\
\text { ( } 3 \\
\text { 首) }\end{array}$ & $\begin{array}{l}\text { 飛来峰 } \\
\left(\begin{array}{l}1 \\
\text { 首) }\end{array}\right.\end{array}$ & $\begin{array}{l}\text { 飛来峰 } \\
(\quad 6 \\
\text { 首) }\end{array}$ & $\begin{array}{l}\text { 飛来峰 } \\
\left(\begin{array}{l}1 \\
\text { 首 })\end{array}\right.\end{array}$ \\
\hline $\begin{array}{l}\text { 冷泉亭 } \\
\left(\begin{array}{l}(1 \\
\text { 首 })\end{array}\right.\end{array}$ & & $\begin{array}{l}\text { 冷泉 } \\
\text { 亭 } \\
(3 \\
\text { 首) }\end{array}$ & $\begin{array}{l}\text { 冷泉 } \\
\text { 亭 } \\
\text { ( } 1 \\
\text { 首) }\end{array}$ & $\begin{array}{l}\text { 冷泉亭 } \\
\quad(2 \\
\text { 首) }\end{array}$ & $\begin{array}{l}\text { 冷泉亭 } \\
(8 \\
\text { 首; } 3 \\
\text { 首 } \\
\text { 「 冷 } \\
\text { 泉」) }\end{array}$ & \\
\hline $\begin{array}{l}\text { 北高峰 } \\
(\quad 2 \\
\text { 首、 } \\
\text { うち } 1 \\
\text { 首 は } \\
\text { 「上北 } \\
\text { 高峰」) }\end{array}$ & $\begin{array}{l}\text { 北高 } \\
\text { 峰 } \\
(1 \\
\text { ( } 1\end{array}$ & $\begin{array}{l}\text { 北高 } \\
\text { 峰 } \\
\text { ( } 1 \\
\text { 首) }\end{array}$ & $\begin{array}{l}\text { 北高 } \\
\text { 峰 } \\
\text { ( } 2 \\
\text { 首) }\end{array}$ & 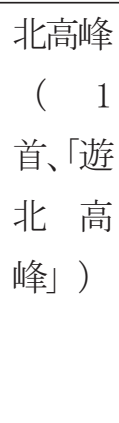 & $\begin{array}{l}\text { 北高峰 } \\
\left(\begin{array}{l}1 \\
\text { 首) }\end{array}\right.\end{array}$ & \\
\hline & & & $\begin{array}{l}\text { 呼猿 } \\
\text { 洞 } \\
(1 \\
\text { 首) }\end{array}$ & & $\begin{array}{l}\text { 呼猿洞 } \\
\left(\begin{array}{l}\quad 5 \\
\text { 首) }\end{array}\right.\end{array}$ & \\
\hline & & & $\begin{array}{l}\text { 九里 } \\
\text { 松 } \\
(6 \\
\text { 首) }\end{array}$ & $\begin{array}{l}\text { 九里松 } \\
\left(\begin{array}{l}(1 \\
\text { 首 })\end{array}\right.\end{array}$ & $\begin{array}{l}\text { 九里松 } \\
\left(\begin{array}{l}(1 \\
\text { 首 })\end{array}\right.\end{array}$ & \\
\hline
\end{tabular}




\begin{tabular}{|c|c|c|c|c|c|c|}
\hline & & & & $\begin{array}{l}\text { 合澗橋 } \\
\left(\begin{array}{l} \\
\text { 首) }\end{array}\right.\end{array}$ & & \\
\hline \multirow{9}{*}{ 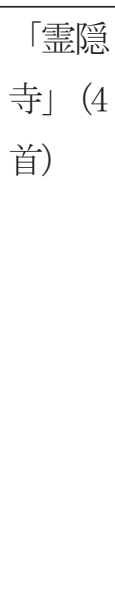 } & 「霊 & 「霊 & 「霊 & & 「霊隠 & 「霊隠 \\
\hline & 隠 & 隠 & 隠 & & 寺」 (4 & 寺」 (4 \\
\hline & 寺」 & 寺」 & 寺」 & & & \\
\hline & ( 1 & ( 3 & ( 9 & & うち 1 & うち 2 \\
\hline & 首) & 首） & 首） & & 首 は & 首は \\
\hline & & & & & 「霊隠 & 「遊霊 \\
\hline & & & & & 寺石」） & 隠寺」、 \\
\hline & & & & & & 1 首は \\
\hline & & & & & & 隠寺」) \\
\hline
\end{tabular}

上の表にまとめた題詩と、上述の梅訽が詠んだ 7 題と を比較すると、共通している題は「本寺 (霊隠寺)」「冷 泉亭」「飛来峰」「猿呼洞」の 4 題であった。ただし「本 寺」或いは「霊隠寺」の題は『扶桑五山記』の 12 題には 含まれていない。

それぞれの形態で、同作者が複数の題詩を詠んでいた が、『扶桑五山記』に含まれている題詩だけに絞ると、 同作者で 3 種類の題を詠んでいるものが「七言絶句」に 1 例あった。しかしその他は、同作者によって詠まれて いる題詩は 2 種類までであった。

「五言古詩」に 10 首中 7 首が収録されていた梅訽（訽 知和尚）については『霊隠寺志』巻五下の「歴代人物」 の章に「梅訽字堯臣知仁和縣事有武陵十詠詩刻石冷泉亭 上xiii」と記載されていた。これによれば、梅訽は仁和県 (杭州市にかつて存在した県) の長官で、彼の詠んだ「武 陵十詠詩」が冷泉亭の傍らに在った石に刻まれていたと いうことがわかる。しかし武陵が湖南省に在る景勝地を 指している可能性があるため、ここに記載されている「武 陵十詠」が「霊隠寺詩十首」と同じものであると断定す ることができない。上述の通り、この「霊隠寺詩十首」 のうちの 7 首は「本寺 (霊隠寺)」「冷泉亭」「飛来峰」

「曲水亭」「龍泓洞」「蓮華石」「呼猿洞」で、『扶桑 五山記』の 12 種類に含まれるのは「冷泉亭」「飛来峰」 「呼猿洞」の 3 首だけである。

霊隠寺については『霊隠寺志』と共に『雲林寺志』に おいても取り上げられている。『雲林寺志』巻六は「詩
詠」に充てられており、3 種類のまとまった題詩が収録 されていた。1 つ目は、郭祥正という同一作者による五 言絶句詩 12 首で、「北高峰塔」「石門澗」「霊隠浦」「合 澗橋」「猿呼洞」「葛塢」「塪光菴」「西菴」「臥犀泉」

「青林洞」「白沙泉」「翻桱臺」の題詩が記載されてい た。また、李考光の詠んだ「霊隠十詠」と、貝瓊の詠ん だ「霊隠十景」という 2 種類の題詩が収録されていた。 この 2 つの題詩は、いずれも五言律詩で詠まれた 10 首の まとまった題詩という点で共通しているが、それぞれ 10 題のなかで同じ題は 3 首しかなかった。「霊隠十詠」の 題は「霊隠寺」「冷泉亭」「蓮花峰」「飛来峰」「鍊丹 井」「猿呼洞」「水臺盤」「翻經臺」「高峰塔」「龍泓 洞」であった。「霊隠十景」の題は「蓮花峰」「龍泓洞」 「葛洪井」「合澗橋」「連巖棧」「飯猿臺」「夢謝亭」 「理公嚴」「題名塔」「猿呼洞」であった。共通してい るのは「蓮花峰」「猿呼洞」「龍泓洞」の 3 題であるが、 これらは同じ韻を持っているわけではなかった。

次に、これらの題を先程の『霊隠寺志』の場合と同じ ように『扶桑五山記』に記載されている 12 種類の題と比 較してみる。『扶桑五山記』の 12 題は「蜚来峯」「直指 堂」「冷泉亭」「猿呼洞」「石蓮峯」「北高峰」「合澗 橋」「壑雷亭」「鷲嶺」「九里松徑」「蓮峯堂」「梅檀 林」であるので、最初の五言絶句詩 12 首の題詩と比較す ると、完全に共通しているのは「合澗橋」と「猿呼洞」 の 2 首で、『雲林寺志』の「北高峰塔」は『扶桑五山記』 の「北高峰」と非常に近いことから、合計で 3 題あると 考える。「霊隠十詠」では、完全に共通しているのは「冷 泉亭」「飛来峰」「猿呼洞」の 3 首で、「霊隠十詠」の 「高峰塔」が『扶桑五山記』の「北高峰」に近い。また 「霊隠十景」では、共通するのは「合澗橋」と「猿呼洞」 の 2 首だけであった。以上のことを表にして以下にしめ した。

『雲林寺志』記載の題詩と『扶桑五山記』記載の題の比 較

\begin{tabular}{|l|l|l|l|}
\hline 扶桑五山記 & 十二首 & 霊隠十詠 & 霊隠十景 \\
\hline 呼猿洞 & 猿呼洞 & 猿呼洞 & 猿呼洞 \\
\hline 北高峰 & 北高峰塔 & 高峰塔 & \\
\hline 合澗橋 & 合澗橋 & & 合澗橋 \\
\hline
\end{tabular}




\begin{tabular}{|c|c|c|c|}
\hline 冷泉亭 & & 冷泉亭 & \\
\hline 蜚来峯 & & 飛来峰 & \\
\hline \multicolumn{4}{|l|}{ 直指堂 } \\
\hline \multicolumn{4}{|l|}{ 石蓮峯 } \\
\hline \multicolumn{4}{|l|}{ 壑雷亭 } \\
\hline \multicolumn{4}{|l|}{ 熟嶺 } \\
\hline \multicolumn{4}{|c|}{ 九里松徑 } \\
\hline \multicolumn{4}{|c|}{ 蓮峯堂 } \\
\hline \multicolumn{4}{|l|}{ 梅檀林 } \\
\hline & & 蓮花峰 & 蓮花峰 \\
\hline & & 龍泓洞 & 龍泓洞 \\
\hline & 石門澗 & 鍊丹井 & 葛洪井 \\
\hline & 葛塢 & 水臺盤 & 連箃棧 \\
\hline & 蓞光菴 & 翻經臺 & 飯猿臺 \\
\hline & 霊隠浦 & 霊隠寺 & 夢謝亭 \\
\hline & 西菴 & & 理公嚴 \\
\hline & 臥犀泉 & & \\
\hline & 青林洞 & & \\
\hline & 白沙泉 & & \\
\hline & 翻經臺 & & \\
\hline
\end{tabular}

以上のことから『扶桑五山記』で挙げられている題は、 必ずしもその封完の境致として広く認識されていたとい うわけではないことが考えられる。「霊隠十詠」や「霊 隠十景」といった「十境」詩に類似した題詩は存在して いるが、10 題に選定された景物は、詠久手によって様及 で、同じ題の方が少ないことがわかる。

\section{（3）天童寺}

『乾道四明図経』巻八に「天童十題」として舒亶 （1041-1103）の詩が収録されている。『天童寺志』には この舒亶の詩が 13 首収録されていたが『乾道四明図経』 とは異なり、まとまった題詩として記載されてはいなか つた。

『天童寺志』巻之一「山川放」は、天童寺の景勝地に ついて述べられた章であるが、景勝地ごとにその説明が あった後、景勝地に対して詠まれた詩が時代を追って収 録されている。この章に舒亶の詩は 8 首収録されており、 そのうちの七言絶句で詠まれた 6 首が「天童十題」詩中
の 6 首と同様の詩であった。残る 2 首は、七言律詩 1 首 と七言排律 1 首で、天童寺山号の「太白山」について詠 んだものであった。 8 首とも、その詩自体には題名がつ いていなかったが、出版社が編集した本の目次には「山 川放」で述べられている景観それぞれに表題が付けてあ り、舒亶の 6 首は「天童十題」と表題と詩がほとんど一 致した。6 首の表題は「太白峰」「玲瓏餀」「響石」「佛 蹟石」「神龍霐」「虎跑泉」である。「天童十題」の中 で上記の 6 首に対応するのは「太白峰」「玲瓏嚴」「響 石」「佛石」「龍池」「虎跑泉」であるが、この中の「佛 石」「龍池」は表題中の「佛蹟石」「神龍霉」との題の 類似や詩が同じであることから、それぞれ対応している ことがわかる。

また、天童寺の建造物について述べた『天童寺志』巻 之二「建置放」に、天童寺の封完周囲に建つ建造物に対 して舒亶が詠んだ詩が 4 首収録されているが、その中の 3 首は、題がついていて『乾道四明図経』に収録されて いる「天童十題」詩中の 3 首と同じ題詩であった。残る 1 首は「山川放」の章の場合と同様に、他の 3 首とは形 態が異なり、七言律詩で詠まれたものであった。この章 で「天童十題」と共通の 3 首は「臨雲閣」「春楽軒」「宿 鷺亭」で、残る七言律詩の題は「蒙堂」であった。残る 1 首「太白庵」は『天童寺志』巻之九「轄麗考 (附莊産)」 に収録されていた。

『天童寺志』に収録されていた舒亶の詩は 13 首であっ たが、そのうち 3 首は「天童十題」に含まれるものでは なく、形態も異なる詩であった。『大童寺志』には舒亶 の「天童十題」詩は全て収録されていたが、10 題まとま った形で記載されているわけではなかった。

以下に舒亶の題詩を表にまとめた。

『乾道四明図経』と『天童寺志』に収録された舒亶の題 詩の比較

\begin{tabular}{|c|c|}
\hline 天童十題 (『乾道四明図経』) & 天童寺志 \\
\hline 太白峰 & 太白峰 \\
\hline 太白庵 & 太白庵 \\
\hline 玲瓏嚴 & 玲瓏餀 \\
\hline 響石 & 響石 \\
\hline 龍池 & 神龍霉 \\
\hline
\end{tabular}




\begin{tabular}{|l|l|}
\hline 虎跑泉 & 虎跑泉 \\
\hline 佛石 & 佛蹟石 \\
\hline 臨雲閣 & 臨雲閣 \\
\hline 春楽軒 & 春楽軒 \\
\hline 宿鴽亭 & 宿鵅亭 \\
\hline & 太白山2 首 (律詩・排律) \\
\hline & 蒙堂 (律詩) \\
\hline &
\end{tabular}

『天童寺志』巻之二「建置放」の康熙五十二年 (1713 年）の中に十景詩が 1 種類收録されていた。これは「太 白山十景詩」と題されており、釋元乗が詠んだものであ る。詩の形式は、潚相八景に倣った七言絶句の題詩が 10 首一揃いになっているものであった。題詩は「深徑廻松」

「青關噴雪」「雙池印景」「西礀分鐘」「玲瓏天輍」「太 白生雲」「東谷秋紅」「南山晚翠」「平臺鋪月」「鳳岡 修竹」の 10 首で、瀟相八景に類似しており、浾相八景同 様に季節毎の情景を表現した題詩が多い。この中で明ら かに季節がわかるのは「青關噴雪」「東谷秋紅」「南山 晚翠」「平臺鋪月」の 4 首であるが、残る 6 首も含めて 自然の中の景観を詠んだ詩集であることは、瀟相八景と 共通している。これは、同じ 10 題の詩集という形式を取 りながら、上記の「天童十題」の題詩とは明らかに異な る特徴である。

「太白山十境詩」と「渃湘八景」の題の比較

\begin{tabular}{|c|c|}
\hline 太白山十景詩 (七言絶句) & 瀟湘八景 \\
\hline 深徑廻松 & 潚湘夜雨 \\
\hline 清關噴雪 & 洞底秋月 \\
\hline 雙池印景 & 煙寺晚鐘 \\
\hline 西礀分鐘 & 遠浦帰帆 \\
\hline 玲瓏大鈢 & 山市晴嵐 \\
\hline 太白生雲 & 漁村夕照 \\
\hline 東谷秋紅 & 江天暮雪 \\
\hline 南山晚翠 & 平沙落雁 \\
\hline \multicolumn{2}{|l|}{ 平臺鋪月 } \\
\hline 鳳|岡修竹 & \\
\hline
\end{tabular}

また日本人入元僧の別源円旨 (1294-1364) が留学先で 記した『南遊集』には「和雲外和尚天童十境韻」の題詩
が収録されているが、『天童寺志』と『天童寺續志』に 雲外雲岫の詩は記載されていなかった。また、雲外雲岫 自身の語録にも十境は収録されていない。しかし雲外雲 岫は、別源円旨の 2 つ著作に序文を残していることが わかっている。『南遊集』のための序文には「南遊集序、 名山勝境、古今題詠者多、詩勝境則境歸於詩、境勝詩則 詩不入境、詩與境合、見詩即見境、境與詩合、見境即見 詩、苟不然、則詩境兩失、日本旨禪者作天童十詠、句意

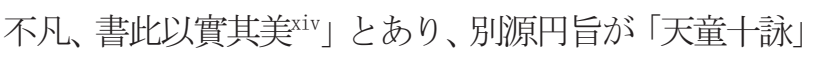
を詠んだことが述べられている。しかし、ここで言われ ている「天童十詠」が『南遊集』に収録されている「天 童十境韻」を指しているのかは定かではない。

『南遊集』に記載された「和雲外和尚天童十境韻」の 10 首は七言絶句の題詩で、「萬松關」「翠鎖亭」「宿鷺 亭」「清關」「萬工池」「登閣」「玲瓏嚴」「虎跑泉」 「龍潭」「太白禪居」である。舒亶の「天童十題」とは、

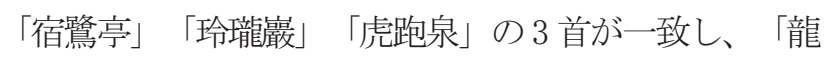
潭」と「太白禪居」の 2 種が類似している。この十境詩 の題のうち「天童十題」と一致していた、あるい蘱似 していた題以外に「萬松關」「翠鎖亭」「淸關」「萬工 池」は「山川放」及び「建置放」の章に記載されており、 複数の作者がそれぞれの題に対して詠んだ詩が収録され ているが、別源円旨の詩は収録されていない。

以下に別源円旨の「和雲外和尚天童十境韻」と舒亶の 「天童十題」の題を表にして比較した。

別源円旨の「和雲外和尚天童十境韻」と舒亶の「天童十 題」の題の比較

\begin{tabular}{|c|c|}
\hline $\begin{array}{l}\text { 和雲外和尚天童十境韻（七 } \\
\text { 言絶句） }\end{array}$ & 天童十題 \\
\hline $\begin{array}{l}\text { 舒亶「天童十題」と共通 } \\
\text { する } 5 \text { 首 }\end{array}$ & \\
\hline 宿鷺亭 & 宿鷺亭 \\
\hline 玲瓏㵊 & 玲瓏㵊 \\
\hline 虎跑泉 & 虎跑泉 \\
\hline 龍潭 & 龍池・神龍䨎 \\
\hline \multirow[t]{2}{*}{ 太白禪居 } & 太白峰 \\
\hline & 太白庵 \\
\hline 『天童寺志』「山川放」「建 & \\
\hline
\end{tabular}




\begin{tabular}{|l|l|}
\hline $\begin{array}{l}\text { 置放」の題詩と共通する } 4 \\
\text { 首 }\end{array}$ & \\
\hline 萬松關 & \\
\hline 翠鎖亭 & \\
\hline 淸關 & \\
\hline 萬工池 & \\
\hline その他 & \\
\hline 登閣 & 臨雲閣 \\
\hline & 春楽軒 \\
\hline & 響石 \\
\hline & 佛石・佛蹟石 \\
\hline
\end{tabular}

以上のことから、天童寺について詠まれた 10 首の題詩 が存在することは確かであるが、10 題が必ずしも一致し ているわけではない。別源円旨の「和雲外和尚十境韻」 と舒亶の「天童十題」は同じ七言絶句で詠まれた 10 首の 題詩であるが、完全に共通しているのは 10 題中の 3 題、 「宿鷺亭」「玲瓏䕾」「虎跑泉」だけであった。

次に舒亶及び別源円旨の 10 首の題詩と『扶桑五山記』 に記載されている題との比較をする。『扶桑五山記』に 記載されているのは「五鳳楼」「光明蔵」「九峯」「龍 潭」「玲瓏嵓」「雙沼」「宿鷺亭」「清關」「萬松關」

「萬工池」「登閣」「妙高臺」「翠鎖亭」「門外二十里 松徑」「虎跑泉」「太白禪居」の 16 題である。このうち、 舒亶の 10 首と完全に共通寸るのは「宿鷺亭」「玲瓏嚴」 「虎跑泉」の 3 題で、類似しているのは「龍池 (神龍雵)」 「太白庵」の 2 題である。別源円旨の 10 首と完全に一致 寸るのは「宿鴽亭」「玲瓏嚴」「虎跑泉」「龍潭」「太 白禪居」「萬松關」「翠鎖亭」「清關」「萬工池」「登 閣」で 10 題全てが一致していることがわかった。反対に 『扶桑五山記』だけに記載されているのは「五鳳楼」「光 明蔵」「九峯」「雙沼」「妙高臺」「門外二十里松徑」 の6題であった。以下にこれらを表にまとめた。

「和雲外和尚十境韻」及び「天童十題」と『扶桑五山記』 記載の題の比較

\begin{tabular}{|l|l|l|}
\hline 『扶桑五山記』 & 別源円旨 & 舒亶 \\
\hline 五鳳楼 & & \\
\hline
\end{tabular}

\begin{tabular}{|c|c|c|}
\hline 光明蔵 & & \\
\hline 九峯 & & \\
\hline 龍潭 & 龍潭 & 龍洢。神龍霉 \\
\hline 玲瓏耑 & 玲瓏巖 & 玲瓏巖 \\
\hline 雙沼 & & \\
\hline 宿鷺亭 & 宿鷺亭 & 宿鷺亭 \\
\hline 清關 & 清關 & \\
\hline 萬松關 & 萬松關 & \\
\hline 萬工池 & 萬工池 & \\
\hline 登閣 & 登閣 & \\
\hline 妙高臺 & & \\
\hline 翠鎖亭 & 翠鎖亭 & \\
\hline 門外二十亘 & & \\
\hline 虎跑泉 & 虎跑泉 & 虎跑泉 \\
\hline 太白禪居 & 太白禪居 & 太向庵 \\
\hline & & 太白峰 \\
\hline & & 響石 \\
\hline & & 佛石・佛蹟石 \\
\hline & & 臨雲閣 \\
\hline & & 春楽軒 \\
\hline
\end{tabular}

以上に見られるように、『扶桑五山記』や別源円旨の 10 題と比較して、舒亶の 10 題はその半数が同一ではない。 これは文献が書かれた国の違いを反映しているものと考 えられる。

\section{(4) 浄慈寺}

『栜建浄慈寺志』に収録されていた一定数のまとまっ た題詩は全て「西湖十景」詩であった。収録されていた のは巻首二の「御製詩扑額聯」の章と巻十四の「園亭一」 の章である。また巻二十五には「藝文二 南屏詩一」、 巻二十六には「藝文二 南屏詩二」という章があり、南 屏を詠んだ詩が収められていた。南屏は『扶桑五山記』 に記載されている 12 種の題の 1 番目に記載されている 「南屏山或云南屏峯」を指寸と考えられるが、これは浄慈 寺の主山である。

「西湖十景」は断橋残雪、平湖秋月、曲院風荷、蘇堤 春暁、三潭印月、花港観魚、南屏晚鐘、雷峰夕照、柳浪 聞鶯、双峰挿雲の 10 首だが、『浄慈寺志』に収録されて 
いるのは「南屏晚鐘」と「雷峰夕照」の 2 種類だけであ った。巻首二は「御製詩林額聯」とあるように皇帝の詠 んだ詩の扁額の対聯を収録した章である。「淸聖祖仁皇 帝御製詩扑額聯和」とある通り、清代第四代皇帝の康熙 帝 (1654-1722) が詠んだと考えられる西湖十景詩の扁額 が掛けられていた。康熙帝の扁額の題は「雷峯西照」と 「南屏晚鐘」と記載されているが、「雷峯西照」は「雷 峰夕照」と同種の題と考えられる。それぞれの題は詩を 伴っておらず、扁額が掛けられていた場所が記載されて いた。「雷峯西照」は「恭鏶石刻在雷峯之真有亭 ${ }^{x v i} 」 と$ あるので、雷峰の頂に有る亭に掛けられていた。また「南

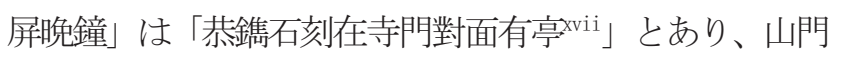
に面して建てられていた亭に掛けられていたことがわか る。収録されていた詩は「南屏晚鐘」「雷峰夕照」がそ れぞれ 7 首で、最初の 1 首ずつが作者の判る和韻詩を伴 っていた。残る 5 首ずつはいずれも疊舊作韻と記載され ており、5 首全てが最初の詩の疊韻詩であった。また巻 十四の「園亭一」には「南屏晚鐘」「雷峰夕照」共に異 なる作者の詩が 27 首ずつ収録されていた。作者は「南屏 晚鐘」と「雷峰夕照」で作者が共通している詩は 27 首中 23 首であった。

『浄慈寺志』には西湖十景中の「南屏晚鐘」と「雷峰 夕照」だけが収録されていたが、これはいずれも浄慈寺 周辺の景観を詠んでいるという理由からと考えられる。 その一方で、郝完に対して選定された「境致」や「十境」 詩、或いは「十景」「十詠」などの記載はなかった。

\section{（5）阿育王寺}

『明州阿育王山志』の巻十上下は「玉几社詠」と題さ れた章で、阿育王寺に対して詠まれた詩が収録されてい る。この中には、ひとまとまりの題詩がいくつか含まれ ていた。

巻十の上には、「阿育王四景」と題して、雪䉷祖欽 (13 世紀）の詠んだ「舎利塔」「望海亭」「無畏堂」「淵靈 廟」の七言絶句詩。「阿育王八景」と題して、それぞれ 作者の異なる 8 首の七言律詩の題詩; 倪光 (明代) の「山 横玉几、杜英の「香管焼雲」、㱀誾の「燈然兩塔」、 史鏞の「井湧金沙」、方震の「鐘度重關」、王政の「螢 照松堂」、倪錀の「鹿鳴芝洞」、蔡欽の「茶鐺㙖月」。 そして樂長卿の「育王山十詠」と題して「舎利塔」「玉
几峰」「金沙井」「仙書岩」「佛石」「七沸潭」「大權 洞」「承恩閣」「涌現离」「妙喜泉」の 10 首の七言絶句 詩である。

『明州阿育王山續志』巻十一には、宋代の官僚楊覃 (958-1011) の「和育王十二題」という題詩が収録され ていた。五言絶句で詠まれた「金沙池」「佛跡峯」「七 沸石」「袈乷衣」「名月臺」「石屏峯」「靈鰻井」「供 奉泉」「育王塔」「八角殿」「晉年札」「重臺蓮」の 12 題である。また巻十二には、阿育王寺第八十代住持の釋 自學（明代）が詠んだ「次十境韻」という七言絶句の次 韻詩が収録されている。題は「舎利塔」「涌現岩」「七 沸潭」「大權洞」「佛跡岩」「仙書岩」「妙喜泉」「宸 奎閣」「金沙井」「玉几峯」であった。そして同じく阿 育王寺第八十四代住持、清源本（明代）の「次十景韻」 が収録されているが、これは前述の釋自學による「次十 境韻」詩と共通の韻を踏んでいることがわかった。

巻十五には、清代の阿育王寺の禅僧である釋畹荃の五 言律詩が 10 首収録されている。題は「涌現岩」「玉几峰」

「金沙井」「放光松」「赤莗峰」「佛蹟亭」「鬼谷祠」

「望海亭」「妙喜泉」「袈裟石」であった。この釋畹荃 の10 首は、「十境」「十景」といった、ひとまとまりの 題詩として収録されてはいなかった。しかし10 題中「涌 現岩」「玉几峰」「金沙井」「妙喜泉」の 4 題は前述の 釋自學の「次十境韻」と共通しており、「望海亭」は雪 嚴祖欽の「阿育王四景」にも入っている。

『阿育王山志』及び『阿育王山續志』には「阿育王四 景」「阿育王八景」「育王山十詠」「和育王十二題」「次 十境韻」「次十景韻」そして釋啘荃の 10 題の合計 7 種類 のまとまった題詩が収録されていた。これらの題詩を種 類ごとにまとめたものが以下の表である。

『阿育王山志』『阿育王山續志』収録の題詩の比較

\begin{tabular}{|c|c|c|c|c|c|c|}
\hline \multirow{6}{*}{$\begin{array}{l}\text { 阿 育 } \\
\text { 王 四 } \\
\text { 景 (七 } \\
\text { 言 絶 } \\
\text { 句) }\end{array}$} & 于 育 & 育 王 & 和 育 & 次 十 & 次 十 & 釋 罒 \\
\hline & 王 八 & 山十 & F & 境 韻 & 景 韻 & 荃 \\
\hline & (七 & 詠 (七 & 二 題 & ( 七 & ( 七 & 十是 \\
\hline & 言 律 & 言 絶 & （五 & 言 絶 & 言 絶 & （五 \\
\hline & & 句） & 言 絶 & & & 言 律 \\
\hline & & & & & & \\
\hline 舎 利 & & 舎 利 & 名 月 & 舎 利 & 舎 利 & 望 清 \\
\hline
\end{tabular}




\begin{tabular}{|c|c|c|c|c|c|c|}
\hline 塔 & 兩塔 & 塔 & 臺 & 塔 & 塔 & 亭 \\
\hline $\begin{array}{l}\text { 望 海 } \\
\text { 亭 }\end{array}$ & $\begin{array}{l}\text { 井 湧 } \\
\text { 金沙 }\end{array}$ & $\begin{array}{l}\text { 金 沙 } \\
\text { 井 }\end{array}$ & $\begin{array}{l}\text { 金 沙 } \\
\text { 池 }\end{array}$ & $\begin{array}{l}\text { 金 沙 } \\
\text { 井 }\end{array}$ & $\begin{array}{l}\text { 金 沙 } \\
\text { 井 }\end{array}$ & $\begin{array}{l}\text { 金 沙 } \\
\text { 井 }\end{array}$ \\
\hline $\begin{array}{l}\text { 無 畏 } \\
\text { 堂 }\end{array}$ & $\begin{array}{l}\text { 山 横 } \\
\text { 玉几 }\end{array}$ & $\begin{array}{l}\text { 玉 几 } \\
\text { 峰 }\end{array}$ & $\begin{array}{l}\text { 八 角 } \\
\text { 殿 }\end{array}$ & $\begin{array}{l}\text { 玉 几 } \\
\text { 峯 }\end{array}$ & $\begin{array}{l}\text { 玉 几 } \\
\text { 峯 }\end{array}$ & $\begin{array}{l}\text { 玉 几 } \\
\text { 峰 }\end{array}$ \\
\hline \multirow[t]{9}{*}{$\begin{array}{l}\text { 淵 靈 } \\
\text { 廟 }\end{array}$} & $\begin{array}{l}\text { 香 管 } \\
\text { 焼雲 }\end{array}$ & $\begin{array}{l}\text { 七 沸 } \\
\text { 潭 }\end{array}$ & $\begin{array}{l}\text { 七 沸 } \\
\text { 石 }\end{array}$ & $\begin{array}{l}\text { 七 沸 } \\
\text { 潭 }\end{array}$ & $\begin{array}{l}\text { 七 沸 } \\
\text { 潭 }\end{array}$ & $\begin{array}{l}\text { 放 光 } \\
\text { 松 }\end{array}$ \\
\hline & $\begin{array}{l}\text { 鐘 度 } \\
\text { 重關 }\end{array}$ & 佛石 & $\begin{array}{l}\text { 佛 跡 } \\
\text { 峯 }\end{array}$ & $\begin{array}{l}\text { 佛 跡 } \\
\text { 岩 }\end{array}$ & $\begin{array}{l}\text { 佛 跡 } \\
\text { 岩 }\end{array}$ & $\begin{array}{l}\text { 佛 蹟 } \\
\text { 亭 }\end{array}$ \\
\hline & $\begin{array}{l}\text { 螢 照 } \\
\text { 松堂 }\end{array}$ & $\begin{array}{l}\text { 仙 書 } \\
\text { 岩 }\end{array}$ & $\begin{array}{l}\text { 石 屏 } \\
\text { 峯 }\end{array}$ & $\begin{array}{l}\text { 仙 書 } \\
\text { 岩 }\end{array}$ & $\begin{array}{l}\text { 仙書 } \\
\text { 岩 }\end{array}$ & $\begin{array}{l}\text { 赤 董 } \\
\text { 峰 }\end{array}$ \\
\hline & $\begin{array}{l}\text { 鹿 鳴 } \\
\text { 芝洞 }\end{array}$ & $\begin{array}{l}\text { 大 權 } \\
\text { 洞 }\end{array}$ & $\begin{array}{l}\text { 靈 鰻 } \\
\text { 井 }\end{array}$ & $\begin{array}{l}\text { 大 權 } \\
\text { 洞 }\end{array}$ & $\begin{array}{l}\text { 大 權 } \\
\text { 洞 }\end{array}$ & $\begin{array}{l}\text { 鬼 谷 } \\
\text { 祠 }\end{array}$ \\
\hline & $\begin{array}{l}\text { 茶 鐺 } \\
\text { 蓦月 }\end{array}$ & $\begin{array}{l}\text { 涌 現 } \\
\text { 䉷 }\end{array}$ & $\begin{array}{l}\text { 供 奉 } \\
\text { 泉 }\end{array}$ & $\begin{array}{l}\text { 涌 現 } \\
\text { 岩 }\end{array}$ & $\begin{array}{l}\text { 涌 現 } \\
\text { 岩 }\end{array}$ & $\begin{array}{l}\text { 涌 現 } \\
\text { 岩 }\end{array}$ \\
\hline & & $\begin{array}{l}\text { 妙 喜 } \\
\text { 泉 }\end{array}$ & $\begin{array}{l}\text { 䏍 王 } \\
\text { 塔 }\end{array}$ & $\begin{array}{l}\text { 妙 喜 } \\
\text { 泉 }\end{array}$ & $\begin{array}{l}\text { 妙 喜 } \\
\text { 泉 }\end{array}$ & $\begin{array}{l}\text { 妙 喜 } \\
\text { 泉 }\end{array}$ \\
\hline & & $\begin{array}{l}\text { 承 恩 } \\
\text { 閣 }\end{array}$ & $\begin{array}{l}\text { 袈 裟 } \\
\text { 衣 }\end{array}$ & $\begin{array}{l}\text { 宸 奎 } \\
\text { 閣 }\end{array}$ & $\begin{array}{l}\text { 宸 奎 } \\
\text { 閣 }\end{array}$ & $\begin{array}{l}\text { 袈乷 } \\
\text { 石 }\end{array}$ \\
\hline & & & $\begin{array}{l}\text { 晉 年 } \\
\text { 札 }\end{array}$ & & & \\
\hline & & & $\begin{array}{l}\text { 重 臺 } \\
\text { 蓮 }\end{array}$ & & & \\
\hline
\end{tabular}

同じ題で色分けすると「育王山十詠」と「次十境韻」 「次十景韻」は 9 題が同じで、残る 1 題も「閣」である ことがわかる。詩の形態も同じ七言絶句であった。確か めると「育王山十詠」詩と「次十境韻」「次十景韻」詩 が共通の韻を踏んで詠まれていることがわかったので 「次十境韻」と「次十景韻」は「育王山十詠」詩の次韻 詩であると考えることができる。また「育王山十詠」の

「承恩閣」が他の 2 題では「宸奎閣」になっているが詩 自体は共通の韻を踏んでいた。宸奎閣は南北に延びる阿 育王寺伽藍の最も北で、中軸の西側に位置しており、蘭 渓道隆が阿育王寺に住持した時に、地元の人々によって 寄進されたものである。北宋第四代皇帝の仁宗（1010 1063）が親書した頌詩の宸翰を奉じたことから宸奎閣と 名づけられた。「承恩閣」については、宸奎閣の南に位 置する方丈殿の一室が承恩堂と呼ばれているxvii ので、方
丈に付随した重層建築物であったと考えられる。これら のことから、題詩の「承恩閣」と「宸奎閣」は別の対象 物について詠まれた詩であるが、「宸奎閣」は「承恩閣」 と同じ韻を踏んでいる和韻詩であると結論づけた。韻は 4 文字中の 2 文字か 3 文字取っている場合が多いが「次 十境韻」詩と「次十景韻」詩の韻の数を比較すると、す べての詩で同数か、あるいは「次十景韻」詩で「次十境 韻」に対する韻がさらに詠み込まれているかのいずれか であった。たとえば「舎利塔」では「次十境韻」詩と「次 十景韻」詩の「育王山十詠」に対する韻は結句の 1 文字 だけであるが、「次十景韻」詩の「次十境韻」詩に対す る韻は承句と結句の 2 文字あった。また「仙書岩」では 「育王山十詠」詩に対する韻は起句、承句、結句の 3 文 字であったが、「次十景韻」詩の「次十境韻」詩に対す る韻はさらに転句も含まれて四句全てで韻を踏んでいた。 これらの例から、「育王山十詠」詩の次韻詩は「次十境 韻」だけで、「次十景韻」は「次十境韻」詩の次韻詩と して詠まれたものであると考えることができる。

以上のことから「育王山十詠」と「次十境韻」「次十 景韻は10 首でまとまった題詩とそれに続く次韻詩であ ることがわかった。次に他の題詩について考察する。ま ず「阿育王四景」は、先述の 3 種類の題詩同様に七言絶 句で詠まれている。しかし先述の 3 種類の題詩と共通し ているのは 4 題中「舎利塔」 1 題だけで、その詩も韻の 共通性は見られない。「望海亭」は、釋晼荃の 10 題にも 含まれている題だが、五言律詩で詠まれている釋踠荃の 詩との共通性はないと言える。残る 2 題は、他のいずれ の題詩にも含まれていなかった。

「阿育王八景」は七言律詩で、題が 4 文字で情景描写 が表現されていることは潚湘八景詩の伝統的技法と共通 する。また七言律詩で詠まれていることも、多くの潚湘 八景詩の形態と共通寸る。これは他の題詩には見られな い「阿育王八景」詩の特徵で、潚泪八景詩に倣った名所 題詩として詠まれたものであると考えられる。

「和育王十二題」は、もととなる 12 題の詩に和した題 詩であると推測されるが、もととなった題詩自体は収録 されていなかった。題になっている景物のいくつかは他 の題詩でも詠まれているが、いずれも他の題詩の題銘と わずかに違う。例えば他の題詩では全て「金沙井」とな っているものが「和育王十二題」では「金沙池」となっ 
ており、他で「七佛澤」となっているものは「七佛石」 となっている。また、題で他の題詩と共通するのは 4 題 だけで、残る 8 題は「和育王十二題」だけに見られる景 物である。題が共通している 4 首についても、詩が五言 絶句で詠まれているので、他の題詩との共通性はない。

最後に釋畹荃の 10 題についてであるが、これは釋畹荃 が詠んだ 10 首の題詩をひとまとめにしたものである。題 が他の題詩と共通しているのは 7 首と多いが、その中で 「育王山十詠」「次十境韻」「次十景韻」と共通寸るの は「金沙井」「玉几峰」「佛石 (亭)」「涌現岩」「妙 喜泉」の 5 題で、残る「望海亭」と「袈乷（石）」の 2 題は「阿育王四景」と「和育王十二題」とそれぞれ 1 題 ずつ共通していた。ただし釋晼荃の 10 題は五言律詩で詠 まれているので、題が共通していても他の題詩との共通 性は見られない。

『明州阿育王山志』『明州阿育王山續志』には 1 種類 の「十境」詩が収録されていた。この題詩は「次十境韻」 とあることから次韻詩であることがわかった。しかしこ の題詩のもととなったと考えられる題詩は「十境」では なく「育王山十詠」としてまとめられていた。また「次 十境韻」詩のさらに次韻詩であると考えられる題詩も収 録されていたが、これは「次十景韻」として記載されて いた。次韻詩を作成する場合でも十詠と十境そして十景 は同意語として扱われていると考えられ、もとの題詩に 倣う必要はないということが言える。このことは禅宗寺 院において「十境」や「境致」が、禅宗固有の特別な概 念として捉えられていたわけではなく、「詠」や「景」 と同等に用いられていたことを示唆するものである。

次に『明州阿育王山志』『明州阿育王山續志』に収録 されていた題詩を『扶桑五山記』に記載されている題と 比較した。『扶桑五山記』に記載されているのは「玉几 峯」「玉几亭」「無畏堂」「妙喜泉」「貿峰」「舎利道 場」「靈鰻池」の7 題である。この中で『明州阿育王山 志』『明州阿育王山續志』の題詩と共通寸る題を取り上 げると、完全に一致するのは「玉几峯」「無畏堂」「妙 喜泉」の 3 題であった。また「靈鰻池」は類似する「靈 鰻井」があった。残る「玉几亭」「貿峰」「舎利道場」 はいずれの題詩にも含まれていなかった。しかしいずれ の題詩も『扶桑五山記』の 4 題の中の 1 題あるいは 2 題 を含むに止まっていた。「玉几峯」と「妙喜泉」は「䏍
王山十詠」及び 2 種類の次韻詩に、「無畏堂」は「阿育 王四景」にそれぞれ含まれており、「靈鰻池」は「和育 王十二題」の「靈鰻井」と共通している。以下は、これ を表にまとめたものである。

『扶桑五山記』記載の題と共通寸る『阿育王山志』『阿 育王山續志』の題詩分類

\begin{tabular}{|l|l|}
\hline 扶桑五山記 & 阿育王山志・續志の題詩 \\
\hline 玉几峯 & 育王山十詠・次韻詩 2 種類 \\
\hline 妙喜泉 & 育王山十詠・次韻詩 2 種類 \\
\hline 無畏堂 & 阿育王四景 \\
\hline 靈鰻池 & 和育王十二題 $($ 「靈鰻井」) \\
\hline
\end{tabular}

以上のことから、『扶桑五山記』に記載されている題 は必ずしも中国仏教寺院志に編纂された題詩と共通して いるわけではないことがわかる。阿育王寺志には南宋五 山封完の寺志の中で唯一「十境」が収録されていたが『扶 桑五山記』に記載されていた題の中で、この十境詩と共 通する題は「玉几峯」と「妙喜泉」の 2 題だけであった。

\section{(6) 小結}

ここまで南宋五山の各郝完の寺志に収録されていた題 詩について分析したが、「十境」詩が収録されていたの は阿育王寺志に 1 種類だけであった。まとまった題詩の 收録は複数あったが、必ずしも 10 首でまとめられている わけではなく、四題、八題、十二題が存在した。まとめ られた題詩に使用されているのは「境」の他に「景」「詠」

「題」などで、最も多く収録されていたのは「景」であ った。これは、天童寺志に「太白山十景詩」、浄慈寺志 には「西湖十景」のうちの 2 題、そして阿育王寺志には 「次十景韻」「阿育王四景」「阿育王八景」の 3 種類が 收録されていたので、五山封完志全てを合計すると 5 種 類であった。「詠」「題」はそれぞれ 1 種類ずつあり、 いずれも阿育王寺志に収録されていた「育王山十詠」と 「和育王十二題」である。五山郝完の寺志には、まとま った形で収録されている題詩が全くない場合も多かった。 萬寿寺には全く収録されておらず、詩はそれぞれ単独で 記載されていた。霊隠寺には「霊隠寺志十首」という記 載があったが、この 10 首がもとは、「境」「景」「詠」 
「題」などでまとまった題詩であったかは定かではない。 浄慈寺には「西湖十景」の記載があったが、収録されて いたのは「西湖十景」詩中の 2 題のみであった。そもそ も「西湖十景」は、純粋に浄慈寺自体に対して詠まれた 詩であるとは言い難い。結論として、まとまった題詩が 収録されているのは、天童寺志の「太白山十景詩」と、 阿育王寺志の「育王山十詠」「次十境韻」「次十景韻」

「阿育王四景」「和育王十二題」「阿育王八景」で、五 山封完中の 2 寺だけであった。そしてこのうちの「太白 山十景詩」と「阿育王八景」は、浄慈寺の「西湖十景」 2 首と同様に「潚泪八景」詩の形式を取っていて、この他 の題詩とは種類が異なる題詩群であるということがわか った。

また、10 首の詩をひとまとまりにして収録している例 だけを取り上げてみると、霊隠寺の「霊隠寺志十首」（霊 隠寺志に収録されているのは 7 首）、天童寺の舒亶の詩 10 首（『乾道四明図経』に収録されている「天童十題」 と同一のもの）と「太白山十景詩」（「蕭湘八景詩」と 同種のもの）、阿育王寺の「育王山十詠」「次十境韻」 「次十景韻」の 6 種類であった。この中で、「太白山十 景詩」は「潚相八景」詩や浄慈寺志に収録されていた「西 湖十景」と同種のものなので、その他の 5 種類とは形式 が異なる。霊隠寺と天童寺のものは、10 首ひとまとまり になった題詩ではないという点で共通している。それに 対して阿育王寺の「育王山十詠」「次十境韻」「次十景 韻」は、日本の禅宗封完で数多く詠まれた「十境詩」に 最も近い型式を取っている。特に「次十境韻」は「育王 山十詠」の次韻詩ではあるが、南宋五山寺院の寺志の中 に収録されていた唯一の「十境詩」である。ただし『扶 桑五山記』に記載されている題と共通の題の詩は 2 首だ けであった。

\section{3. 中国禅宗寺院で詠まれた題詩が冠する「詠」、「景」、 「境」それぞれの特徵や違い}

\section{（1）「詠」、「景」、「境」それぞれが使用される傾} 向について

これまで中国禅宗寺院の中の南宋五山寺院について、 『中國佛寺志彙刊』のそれぞれの文献から、詠まれた題 詩の分類をおこなってきた。そこで本章では、南宋五山 郝完以外の仏教封院でも、同じような題詩が詠まれてい
たのかを確かめるため『中國佛寺志彙刊』に入っている 他の仏教寺院志を調べて、記載されている題詩の種類と その数の統計を取った。その結果、五山封完以外の仏教 封完でも多くのまとまった題詩が詠まれていることがわ かった。最も多くみられるのは「景」で11 種類あった。 次に「詠」が 3 種類で、残る 1 種は名称を伴わずにひとま とまりの題詩として収録されていた。しかし、「境致」 や「十境」と銘打たれた題詩は確認できなかった。11種 類の「景」と 3 種類の「詠」の特徵を挙げると、「詠」 の題詩は全て 10 首でひとまとまりであるのに対して、「景」 は 10 首ひとまとまりが 11 種類中 8 種類で、その他 6 首、 8 首、14 首でまとまっているものが 1 種類ずつあった。

上記の結果に五山寺院の題詩をふくめた場合でも「景」 の題詩が最も多く、17 種類であった。その中で「十景」 は 12 種類で、それ以外は「四景」「六景」「十四景」が それぞれ 1 種類ずつ、「八景」が 2 種類であった。また、

「詠」の題詩は 5 種類で、その全てが「十詠」であった。

「景」と「詠」以外の例としては、『阿育王寺志』に収 録されていた「和育王十二題」と「次十境韻」が挙げら れる。このことから『中國佛寺志彙刊』に收録されてい る、まとまった題詩の多くは10 首でひとまとまりとされ ているということが明らかとなった。

まず「詠」は必ず 10 首でひとまとまりとなっていた。収 録数では「十景」が一番多いが「景」には 10 首以外でひと まとまりとなっている例もあった。ただ、10 首以外の場 合も「四景」「六景」「八景」「十四景」と、必ず偶数 でまとめられていた。また次韻詩が収録されていたが、 もとの題詩が「十詠」であるのに対して韻詩は「十境」 としてまとめられており、さらに「十境」詩の韻詩が「十 景」としてまとめられていた。これは「十詠」、「十景」、

「十境」が同一の意味で用いられていたこと、さらにそ れらを用いる場合には、それぞれに明確な区別がなされ ていなかったことを示すものと考えられる。

ここまで、各郝完志に記載された題詩を主にひとまとま りになった題詩の数によって整理してきた。次に、この 結果を踏まえた上で、それぞれの題詩の特徵を分類し、

「詠」「景」「境」という表題の違いが、詩に詠まれる 対象の違いや特徵に関係しているのかを検討した。初め に、これまでに題詩を挙げた全ての封完について、それ ぞれの『寺志』に収録されていた題詩と共に記述する。 
封院ごとに整理し、まとまった題詩が名称を冠して収録 されていた場合はその名称、同一作者によるまとまった 題詩の場合はその作者名、それ以外の場合は本文で使わ れている名称を用いて記載した。最初に南宋五山封完の 5 寺について記載し、次に、それ以外の仏教封院で題詩 の記載が確認できた寺院を、題詩と共に全て挙げた。

\section{(i) 萬寿寺}

萬寿寺には、1 種類が確認された。題詩に対する名称 はなく、作者の記載もなかった。『寺志』に記載されて いた名称は「偈詠」で、「掲石 (嚴)」「凌霄 (閣・庵)」 「含暉亭」「盤陀石」「靈雞塚」「妙喜庵」の6 題であ つた。

\section{(i i ) 霊隠寺}

霊隠寺には、 5 種類確認できた。 $2 つ は$ 作者名の記載が あり、題詩に対寸る名称がなかった。梅訽の題詩は 7 首 で、「本寺 (霊隠寺)」「冷泉亭」「飛来峰」「曲水亭」 「龍泓洞」「蓮華石」「猿呼洞」である。郭祥正の題詩 は 12 首で、「北高峰塔」「石門澗」「霊隠浦」「合澗橋」 「猿呼洞」「葛塢」「蓞光菴」「西菴」「臥姩泉」「青 林洞」「白沙泉」「翻經臺」である。

題詩に対する名称がなく、「詩詠」として記載されて いたものが 6 首あり、題は「飛来峰」「冷泉亭」「北高 峰」「猿呼洞」「九里松」「合澗橋」である。

題詩に対して名称が付いていたものが、2 種類あった。 1つは、「霊隠十詠」で、題は「霊隠寺」「冷泉亭」「蓮 花峰」「飛来峰」「鍊丹井」「猿呼洞」「水臺盤」「翻 經臺」「高峰塔」「龍泓洞」である。もう 1 つは「霊隠 十景」で、題は「蓮花峰」「龍泓洞」「葛洪井」「合澗 橋」「連嚴棧」「飯猿臺」「夢謝亭」「理公嚴」「題名 塔」「猿呼洞」である。

\section{(i i i ) 天童寺}

天童寺には作者の名前で収録された題詩が 2 種類あつ た。舒亶の題詩は、「太白峰」「玲瓏巖」「響石」「佛 蹟石」「神龍霉」「虎跑泉」「臨雲閣」「春楽軒」「宿 鷺亭」「太白庵」の 10 題である。釋元乗は、「深徑迴松」 「青關噴雪」「雙池印景」「西礀分鐘」「玲瓏天殓」「太 白生雲」「東谷秋紅」「南山晚翠」「平臺鋪月」「鳳岡
修竹」の 10 題で、「潚湘八景」詩の形式の題であること がわかる。

\section{（iv）浄慈寺}

浄慈寺については、『寺志』に西湖十景との記載があ り、「南屏晚鐘」「雷峰夕照」の 2 題が収録されていた。

\section{（v）阿育王寺}

阿育王寺には 6 種類の題詩が収録されていた。そのう ちの 5 種類には題詩に名称が付けられていた。残る 1 種 は作者名での収録であった。

「阿育王四景」は「舎利塔」「望海亭」「無畏堂」「淵 靈廟」の 4 題が記載されている。「阿育王八景」は、「山 横玉几「香管焼雲」「燈然兩塔」「井湧金沙」「鐘度 重關」「螢照松堂」「鹿鳴芝洞」「茶鐺蓦月」で、「潚 湘八景」詩の形式である。「育王山十詠」は、「舎利塔」

「玉几峰」「金沙井」「仙書岩」「佛石」「七沸潭」「大 權洞」「承恩閣」「涌現嚴」「妙喜泉」である。「和育 王十二題」は、「金沙池」「佛跡峯」「七沸石」「袈乷 衣」「名月臺」「石屏峯」「靈鰻井」「供奉泉」「育王 塔」「八角殿」「晉年札」「重臺蓮」が記載されている。 そして「次十境韻」と「次十景韻」は同じ 10 題に対して 詠まれた詩で、題は「舎利塔」「涌現岩」「七沸潭」「大 權洞」「佛跡岩」「仙書岩」「妙喜泉」「宸奎閣」「金 沙井」「玉几峯」である。

作者の名前で収録されていたのは、釋畹荃の 10 首で、 「涌現岩」「玉几峰」「金沙井」「放光松」「赤董峰」 「佛蹟亭」「鬼谷祠」「望海亭」「妙喜泉」「袈裟石」 である。

\section{（vi）聖水寺}

聖水寺には、「山中十詠」という名称の題詩が収録さ れており、その題は「聖水寒嚴」「塔基松樂」「振衣亭」 「超然亭」「一滴泉」「三台石」「西山晴雪」「東嶺翠 濤」「古堞秋雲」「長廊夜月」である。これは「潚相八 景」詩形式の題と景物の名称の題が 10 題の中に混在して おり、統一されていない。

\section{（vi i）峨眉山}

峨眉山は「峨眉十景」が詠まれており、題は「潚湘八 
景」形式の「金頂祥光」「靈巖疊翠」「聖寺晚鐘」「象 池夜月」「白水秋風」「洪椿曉雨」「雙橋清音」「九老 仙府」「大坪霏雪」「羅峯晴雲」である。

\section{(iix) 戒壇寺}

戒壇寺の「寶極觀十景」は「弧雲訪道」「赤脚談玄」 「蒼松雪鶴」「玉沼金鱗」「祖庭秋月」「仙閣朝霞」「觀 橋春水」「環林夕照」「石壇丹桂」「玄戋緋桃」の 10 題である。

\section{（ix）雲棲寺}

雲棲寺の「雲棲六景」は「迴耀峯」「寶刀ロウ（山編 に龍）」「壁觀峯」「青龍泉」「聖義泉」「金液泉」の 6 題である。

\section{（x）華厳教寺}

華厳教寺の題詩は名称が付いておらず、景物として、 「玉岑簏峙」「慧澗環流」「箕泉瀉珠」「蛟窗横鐵」「石 窩怪石」「雕礎神工」「輪藏凌雲」「普門却暑」「瑞光 古像」「徑閣幽觀」の 10 題が収録されている。

\section{(xi）棲霞寺}

棲霞寺は、題詩に名称が付いたものが 2 種類あった。 先ず「遊攝山十二首詩韻」には、「綵虹明鏡」「幽居」 「般若臺」「桃花澗」「紫峰閣」「玉冠峯」「千佛巖」 「九株松」「疊浪崖」「萬松臺」「白鹿泉」「最高峯」 の 12 題が記載されている。そして「題棲霞十景」には、 「棲霞山」「玲峯池」「紫峯閣」「萬松山房」「天開厳」 「幽居菴」「疊浪崖」「珍珠泉」「彩虹明鏡」「德雲菴」 の 10 題が記載されている。

\section{（xi i ）廣濟寺}

廣濟寺は「十景詩」として、「梵閣春雲」「徑臺夜月」 「中庭放鶴」「別室馿猿」「花開方丈」「香臭深窗」「院 樹秋陰」「海棠晚色」「大椿團蕒」「仙䴿垂珼」の 10 題が記載されている。

\section{(xi i i) 慶雲寺}

慶雲寺は題詩の名称が付けられているものが4種類 収録されていた。「題鼎湖十景」は、「湖山鼎峙」
「峡水朝宗」「憩菴環翠」「小歇辜峯」「方池月印」「曲 徑雲封」「龍澤飛瀑」「鳳嶺踈鐘」「菩提花雨」「塔院 香風」の 10 題である。「鼎湖十景」は、「湖山鼎峙」「峡

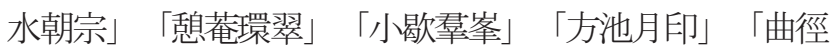
雲封」「龍澤飛瀑」「鳳嶺踈鐘」「菩提花雨」「塔院香 風」の 10 題である。「天湖十四景」は、「折路勝空」「曲 泉尋海」「虎徯煙鎖」「鳳顗雲過」「石塔淩霄」「袈裟 布地」「碧潭龍舞」「瀑澗猿啼」「黛山暮雨」「壁嶂晡 雲」「石徑行僧」「松陰踞客」「肎臺澹月」「龍井疎星」 の 14 題である。「慶雲十詠」は、「湖山鼎峙」「峡水朝 宗」「㮩庵環翠」「小歇韋峰」「方池月印」「曲徑雲封」 「龍澤飛瀑」「鳳嶺踈鐘」「菩提花雨」「墖院香風」の 10 題である。

\section{（xiv）増城海門寺}

増城海門寺は同じ 10 題に対して 3 種類の詩が収録され ていた。1つは題詩に名称が付けられておらず「十景詩」 として収録されていた。残る 2 つ名称がついており、 それぞれ「華峯十詠」と「華峯十景詩」であった。その 10 題は、「斷塵石僧歸」「整衣臺晚朓」「觀瀑臺雨䨚」 「一葉軒乗涼」「聽琴石流泉」「蝴蝶洞深花」「阿耨池 月印」「臥雲洞枕石」「梅花亭賞雪」「太古居談經」で ある。

また、「羊城八景詩」と題された詩の中で 2 題だけが 収録されていた。題は「蒲澗濂泉」「景泰㑭歸」である。

\section{（2）「詠」、「景」使用時に傾向について}

本節では、前節でまとめた各赫の題詩を「詠」「景」 などの名称ごとに分け、さらにその中で題詩の種類ごと に区分けした。こうすることにより、「詠」や「景」が どのような種類の詩詠の時に使用されるかという傾向が 明らかになると考えた。

題詩の種類の違いは大きく 2 種類あると考える。一つ は『扶桑五山記』の日本の禅宗封院の章に記載されてい る「境致」と同様に景物の名称をそのまま題としている もの、もう一つは「潚相八景」詩の題と同様に景観の情 景を描写しているものである。この、景物の名称をその まま題にしている詩と潚相八景のような所謂「八景」詩 の違いは非常に明確である。本稿では便宜上「境致」系 と「瀟相八景」系という語を使用して区別をおこなった。 
ここで言う「境致」系の題詩には「境」だけではなく「景」 や「詠」を冠しているものも含まれているが、いずれも 題に選ばれている場所が対象となる景物の名称そのもの であるという点で共通するものを分類した。それに対し て「瀟相八景」系については、これも「景」とは限らず 「詠」を冠した例も多く在る上に、題詩の数も 8 首であ るとは限らない。それでも「潚泪八景」系に分類する根 拠として、題が 4 文字で表されている例が殆どであるこ と、そしてその題は景物の名称ではなく、景物を含む景 観を描写しているものであるということが挙げられる。 また次章では詩の内容についての分析をおこなっている が、詠まれている詩の内容についても「境致」系の題詩 と「潚相八景」系の題詩では違いが見られる。即ち「境 致」系の詩では、題に選ばれている景物に対する観念的 な説明を試みる内容であるのに対して、「潚泪八景」系 の題詩では、景観に対する情景描写が中心で、「境致」 系の詩と比較してより文学的であると言えよう。

\section{(i) 詠}

「境致」系には以下の 3 種類が確認できた。

(1)霊隠十詠「霊隠寺」「冷泉亭」「蓮花峰」「飛来峰」

「鍊丹井」「猿呼洞」「水臺盤」「翻經臺」「高峰塔」 「龍泓洞」

(2)霊隠十景「蓮花峰」「龍泓洞」「葛洪井」「合澗橋」 「連嚴棧」「飯猿臺」「夢謝亭」「理公嚴」「題名塔」 「猿呼洞」

(3)育王山十詠「舎利塔」「玉几峰」「金沙井」「仙書岩」

「佛石」「七沸潭」「大權洞」「承恩閣」「涌現巖」「妙 喜泉」

「渃湘八景」系には以下の 2 種類が確認できた。

(1)慶雲十詠「湖山鼎峙」「峡水朝宗」「啾庵環翠」「小 歇韋峰」「方池月印」「曲徑雲封」「龍澤飛瀑」「鳳嶺 踈鐘」「菩提花雨」「墖院香風」

(2)山中十詠「聖水寒嶩」「塔基松樂」「振衣亭」「超然 亭」「一滴泉」「三台石」「西山晴雪」「東嶺翠濤」「古 堞秋雲」「長廊夜月」

山中十詠は「境致」系と「潚湘八景」系の題が混在し ていることがわかる。 (ii) 景

a) 十首で一まとまりになっているものを、さらに「潚湘 八景」系と「境致」系の 2 種類に分類した。

「潚湘八景」系には以下の 7 種類が確認できた。

(1)西湖十景「南屏晚鐘」「雷峰夕照」

(2)峨眉十景「金頂祥光」「靈䉷疊翠」「聖寺晚鐘」「象 池夜月」「白水秋風」「洪椿曉雨」「雙橋清音」「九老 仙府」「大坪震雪」「羅峯晴雲」

（3寶極觀十景「弧雲訪道」「赤脚談玄」「蒼松雪鶴」「玉 沼金鱗」「祖庭秋月」「仙閣朝霞」「觀橋春水」「環林 夕照」「石壇丹桂」「玄圃緋桃」

(4)十景詩「梵閣春雲」「徑臺夜月」「中庭放鶴」「別室 馴猿」「花開方丈」「香泉深窗」「院樹秋陰」「海棠晚 色」「大椿團菕」「仙霖垂瓔」

(5)題鼎湖十景「湖山鼎峙」「峡水朝宗」「锶荑環翠」「小 歇韋峯」「方池月印」「曲徑雲封」「龍澤飛瀑」「鳳嶺 踈鐘」「菩提花雨」「塔院香風」

(6)鼎湖十景「湖山鼎峙」「峡水朝宗」「数㟟環翠」「小 歇韋峯」「方池月印」「曲徑雲封」「龍澤飛瀑」「鳳嶺 踈鐘」「菩提花雨」「塔院香風」

(7)十景詩・華峯十詠・華峯十景詩「斷塵石僧歸」「整衣 臺晚眺」「觀瀑臺雨䨎」「一葉軒乗涼」「聽琴石流泉」

「蝴蝶洞深花」「阿耨池月印」「臥雲洞枕石」「梅花亭 賞雪」「太古居談經」この題詩は漢字五文字で構成され ているが、上述の十景の題詩と同様に情景を描写する題 であることから「渃相八景」系に含めてよいと考える。

「境致」系には以下の 2 種類が確認できた。

(1)題棲霞十景「棲霞山」「玲峯池」「紫峯閣」「萬松山 房」「天開巖」「幽居莒」「疊浪崖」「珍珠泉」「彩虹 明鏡」「德雲菴」

(2)次十境韻・次十景韻「舎利塔」「涌現岩」「七沸潭」 「大權洞」「佛跡岩」「仙書岩」「妙喜泉」「宸奎閣」 「金沙井」「玉几峯」

b）10 首で一まとまりにはなっていない題詩を、さらに 「潚湘八景」系と「境致」系に分類した。

「浾湘八景」系には以下の 3 種類が確認できた。 (1)阿育王八景「山横玉几」「香管焼雲」「燈然兩塔」「井 湧金沙」「鐘度重關」「螢照松堂」「鹿鳴芝洞」「茶鐺 
者月」

(2)羊城八景詩 (2 題) 「蒲澗濂泉」「景泰僧歸」

(3)天湖十四景「折路勝空」「曲泉尋海」「虎慀㖶鎖」「鳳 顗雲過」「石墖凌霄」「袈乷布地」「碧潭龍舞」「瀑澗 猿啼」「黛山暮雨」「壁嶂晡雲」「石徑行僧」「松陰踞 客」「肎臺澹月」「龍井疎星」

「境致」系には以下の 2 種類が確認できた。 (1)阿育王四景「舎利塔」「望海亭」「無畏堂」「淵靈廟」 (2)雲棲六景「迴耀峯」「寶刀ロウ（山編に龍）」「壁觀 峯」「青龍泉」「聖義泉」「金液泉」

\section{c）その他の形式で、さらに潚湘八景」系と「境致」系「に}

\section{分類した。}

「潚湘八景」系には以下の 2 種類が確認できた。 (1)釋元乗（10 首）「深徑廻松」「青關噴雪」「雙池印景」 「西礀分鐘」「玲瓏天数」「太白生雲」「東谷秋紅」「南 山晚翠」「平臺鋪月」「鳳岡修竹」

(2)景物（10 首）「玉岑㪘峙」「慧澗環流」「箕泉瀉珠」 「蛟窗横鐵」「石窩怪石」「雕礎神工」「輪藏凌雲」「普 門却暑」「瑞光古像」「徑閣幽觀」

「境致」系には以下の 8 種類が確認できた。

(1)舒亶（10 首）「太白峰」「玲瓏慜」「響石」「佛蹟石」 「神龍霉」「虎跑泉」「臨雲閣」「春楽軒」「宿䉆亭」 「太白庵」

(2)釋晼荃（10 首）「涌現岩」「玉几峰」「金沙井」「放 光松」「赤堇峰」「佛蹟亭」「鬼谷祠」「望海亭」「妙 喜泉」「袈乷石」

(3)偈詠（6 首）「掲石（瞰）」「凌霄 (閣・庵)」「含 暉亭」「盤陀石」「靈雞塚」「妙喜庵」

(4)詩詠（6 首）「飛来峰」「冷泉亭」「北高峰」「猿呼 洞」「九里松」「合澗橋」

(5)梅訽 (10 首中 7 首収録)「本寺 (霊隠寺)」「冷泉亭」 「飛来峰」「曲水亭」「龍泓洞」「蓮華石」「猿呼洞」 (6)郭祥正 (12 首)「北高峰塔」「石門澗」「霊隠浦」「合 澗橋」「猿呼洞」「葛塢」「楿光菴」「西菴」「臥姩泉」

「青林洞」「白沙泉」「翻經臺」

(7)和育王十二題「金沙池」「佛跡峯」「七沸石」「袈裟 衣」「名月臺」「石屏峯」「靈鰻井」「供奉泉」「育王
塔」「八角殿」「晉年札」「重臺蓮」

8)遊攝山十二首詩韻「綵虹明鏡」「幽居」「般若臺」「桃 花澗」「紫峰閣」「玉冠峯」「千佛踂」「九株松」「疊 浪崖」「萬松臺」「白鹿泉」「最高峯」

\section{（i i i 「「詠」と「景」が使用される傾向についての分析}

これまで「詠」と「景」を冠した名称を持つ題詩を、 「蕭相八景」系と「境致」系の 2 種類に分類した。その 中で 2 種類の題詩がそれぞれ幾つあるかを以下にまとめ た。

\section{a) 詠}

「詠」を冠する題詩は全て 10 首で一まとまりになって いた。その中で「境致」系が 3 種類、「浾湘八景」系が 1 種類であった。また「境致」系と「溈湘八景」系が混 在していたものが 1 種類あった。その合計は 5 種類であ る。

\section{b）景}

「景」冠寸る題詩は 10 首一まとまりのものと、そうで ないものがあった。10 首一まとまりだったもののうち、 「浾相八景」系は 9 種類、「境致」系は 3 種類であった。 その合計は 12 種類であった。また、10 首一まとまりで はないものについては、「潚湘八景」系が 3 種類（その うち、八景が 2 種類、十四景が 1 種類) で、「境致」系 が 2 種類（四景、六景が 1 種類ずつ）であった。その合 計は 5 種類である。

\section{c）その他}

上述した $a 、 b$ のずれにも当てはまらないものについ ては、「境致」系が 8 種類で、 10 首が 3 種類、6 首が 2 種類、12 首が 3 種類であった。ただし、10 首 3 種類中の 1 種類は 7 首の夕の収録であった。「浾湘八景」系は 2 種類で、いずれも 10 首一まとまりであった。その合計は 10 種類である。

以上のことについて、まず「詠」でまとめられた題詩 は全て 10 首で一揃い（「十詠」）となっていることが注 目される。題詩の名称はどれも、「十詠」の頭に場所の 名前を冠している。そして題の種類については、景物の 
名称をそのまま使用している「境致」系の方が多く、そ れはいずれも五山封完で詠まれたものであった。

それに対して「景」の題詩では、10 首で一まとまりに なっているもの（「十景」）もそれ以外の数で一まとま りになっているものも、景観の情景を描写する「潚相八 景」系の数が多かった。10 首以外の数で一まとまりのも のでは、「八景」が 2 種類あったが、これはそのまま「潚 湘八景」詩を連想する題詩である。特に「阿育王八景」 については、八景詩が 8 首全て収録されており、先の『阿 育王寺志』のところでも述べたが、「潚相八景」詩と類 似した特徵を持っている。それでも双方の題を比較して みると、「阿育王八景」の方は「瀟相八景」の題ほど抒 情的ではないように思われる。比較するため、以下に双 方の題を列記した。

阿育王八景：「山横玉几」「香管焼雲」「燈然兩塔」「井 湧金沙」「鐘度重關」「螢照松堂」「鹿鳴芝洞」「茶鐺 老月」

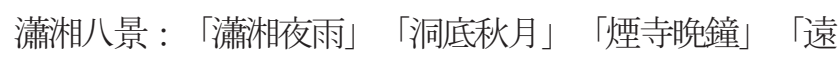
浦婦帆」「山市晴嵐」「漁村夕照」「江天暮雪」「平沙 落雁」。

このように、「阿育王八景」の題は、情景ではなくそ の時の状況を描写したものが多いことがわかる。いずれ にしても「景」の題詩の特徵は「詠」とは対照的に「潚 湘八景」から派生した題詩が中心になっていると考えら れる。

最後に「詠」や「景」という名称が冠されていない題 詩についてであるが、これは「境致」系の題のものが 8 種類で「潚湘八景」系の題のものが 2 種類と、「境致」 系のものの方が多かった。

全体を見ると、「境致」系が 16 種類、「潚泪八景」系 が 15 種類、混在したものが 1 種類なので、どちらかに偏 っているわけではないことがわかる。また、10 首一まと まりの題詩が 22 種類なのに対して、それ以外の数で一ま とまりの題詩は 10 種類であることから、10 首で一まと まりとする「十詠」「十景」が一般的だったことが言え る。「景」の題詩については「潚相八景」と同様の「八 景詩も含まれていたが、その数は 2 種類と少なかった。 また「溈湘八景」系の題を持つ 15 種類の題詩についても、 そのうちの 12 種類が 10 首一まとまりで構成されていた。 中でも「景」の名称を冠している「菠湘八景」系の題詩
については、8 首一まとまりなものは 2 種類であったの に対して、10 首一まとまりなものは 9 種類あり圧倒的に 多い。このことからも、郝完で詠まれた題詩については、 題の種類が「境致」系と「潚湘八景」系のどちらの場合 でも 10 首で一まとまりとする形式が最も一般的であっ たと考えられる。

上述した寺院は、五山封院をはじめとして殆ど全てが 禅宗の封院であったが、廣濟寺（北京市。現在の弘慈広 済寺) だけは禅宗封院ではない。題詩は十景詩と題され た「潚相八景」系の 10 首一まとまりのもので「題詠」の 章に収録されているが、それ以外に巻頭には 10 題それぞ れの景観図が収録されている すべてが寺域内の情景を描写したものであることがわか る。

\section{5.「詠」「景」「境」について文字の音声による違い の分析}

それでは「詠」「景」「境」は、上述の『阿育王寺 志』に収録されていた 10 首の題詩 3 種類（「十詠」と、 その次韻詩である「十境」、「十景」）に見られるよう に、混同されて使用されていたと言えるのであろうか。 先にも述べたように『中國佛寺志』全巻に収録されてい た題詩の中で「十境」詩は『阿育王寺志』の「次十境韻」 詩だけであった。しかし「十詠」詩や「十景」詩は数多 くの例が見いだせるので、 10 首一まとまりの題詩を詠む ことは盛んに行われていたようである。そのため、中国 の封完では、特化した形式の下で十境詩を詠むというこ とが日本の禅宗封完のように盛んには行われていなかっ たのかもしれない。或いは、「詠」「景」「境」のいず れを使用しても同じような意味合いで受け止められてい たのだろうか。そこで「詠」「景」「境」の 3 字は、音 や意味から混同しや寸い文字であるのかを検証した。(中 古音、『中原音韻』音は藤堂明保編『学研和漢大字典』 2001 年版に依った）

\section{それぞれの文字の字音：}

境《上梗》jìng（現代音） - kl $\Lambda \mathrm{n}$ （中古音） - kiəø（『中 原音韻』)

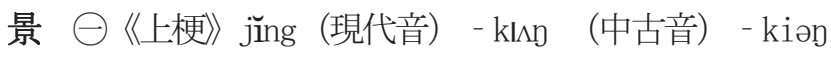
(『中原音韻』) 
$\ominus$ 《上梗》y Ing (影) - 1 n （中古音） - iən（『中 原音韻』)

詠《去敬》 yŏng（現代音） - filu^y（中古音） - ion（『中 原音韻』)

これをみると、現代音では「境」と「景」のきで、ど ちらの文字も jing と発音されており、違いは母音【i】 の声調であることがわかる。境」の母音は第四声の【い、

「景」の母音は第三声の【〕】なので、単語を発音する時 のアクセントには明らかな違いがある。中古音や『中原 音韻』ではアクセントの位置が明確ではないが、「境」 と「景」はどの時代においても殆ど同音であったことが わかる。「詠」については、中古音の母音【1】【んと 子音【り】が、また『中原音韻』の母音【i】と子音【り】 が「境」「景」と共通している。ただし中古音では【u】 が【1】と【いの間に入っているし、『中原音韻』では 母音が【】である。以上の事柄から、「境」「景」「詠」 の 3 文字は比較的近い音で発音される文字ではあるが、

「境」と「景」が近似しているのと比較して「詠」との 共通性は多くないと言える。

中国禅宗封院で詠まれた題詩は、種類別に分類すると 「景」を冠した題詩が最も数多く詠まれていたことがわ かるが、「景」の題詩は「詠」（または「境」）の題詩 と比較すると一まとまりにされる数も様々で、題の種類 も「境致」系と「瀟相八景」系が混在している。このた め考えられるのは、先ず「景」を冠した題詩が詠まれて、 その中の「十景」が視覚からではなく聴覚から混同され て、次第に別の文字を冠した題詩が詠まれるようになっ たということである。『中原音韻』に依る音声を例に取

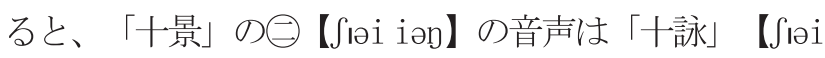
ion】と混同されや寸いと考えられるし、「十景」 $\ominus$ 【

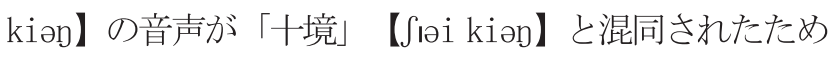
に「十境」という名称が使用されるようになったという 仮説が立てられる。それを裏付ける例として北宋の禅僧 であった覚範恵洪（1071 - 1128）の『石門文字禅』巻八 に収録されている「潚相八景」詩の序が挙げられる。そ こには「宋廸作八境絶妙人謂之無聲句演上人戯余曰道人 能作有聲乎因爲之各賦一首 ${ }^{\mathrm{xx}} 」$ と書かれている。この中 で覚範恵洪は、宋廸（11 世紀後半）の浾湘八景図と詩の 関係を説いているが、「八景」のことが「八境」と表現
されているのがわかる。この例をみても、「景」と「境」 は混同されて使用されることが少なからずあったと言え るだろう。

しかし、上記の考えでは『明州阿育王山志』と『明州 阿育王山續志』に収録されていた 3 種類の題詩の作成順 序の説明がつかない。『明州阿育王山志』『明州阿育王 山續志』によると、これらの 3 種類の題詩は先ず、樂長 卿の「育王山十詠」が詠まれ、次に阿育王寺第八十代住 持、釋自學の「次十境韻」、続いて同じく阿育王寺第八 十四代住持、清源本の「次十景韻」が「育王山十詠」詩 の次韻詩とさらにその次韻詩として詠まれている。何故 「十詠」の次韻詩が「十境」になり、その「十境」の次 韻詩が「十景」になったのかは明確ではないが、この場 合では「十詠」【〕ゃi ion】が「十景」2 種類の音声とい う中継を経ずに「十境」【〕ゃi kiøn】に変化したことに なるので、先に行った音声による文字の混同といら説で は説明が付けられない。何故なら、これまで行ってきた 検討では「景」と「詠」との混同、或いは「景」と「境」 との混同に対しては音声が類似しているためという説明 を付けてきたが、先に挙げた「阿育王山十詠」に対して 詠まれた次韻詩が何故「次十境韻」という名称になった のかは、この検討では説明できない。「景」を介さない で「詠」【ion】と「境」【kion】の音声が混同されたと いうことは考えにくいからである。

蔡敦達は、その論文『中世の禅院空間に関する研究』 で、中国五山寺院では『佛寺志』の記載に、「境致」と いう単語の代わりに「景致」という単語を同じ意味とし て使用しているのではないかと述べている。「景致」と いう単語については、『中國佛寺志』全文献中 14 寺志の 本文中にそれぞれ一か所ずつ計 14 回の記載が確認でき る。しかし、それらが使用されている文章の文脈を検証 すると、例えば『霊隠寺志』では晦山戒顯 $(1610$ - 1672) の「募化絫石增靈隱山門景致疏」と題された一文が収録 されており、続く文章は霊隠寺の景勝地について述べら れたものであることが確認できるxxi。のように「景致」 という単語は景観、景勝といった意味で使用されている と考えられ、日本の禅宗郝完において意味付けされ、使 用されていた「境致」といら単語と同義語として使用さ れたとは考えられない。漢字の意味を見ると、

「境」：(1)さか、境界。くぎり目。「国境」2さかい 
の内側。しきられた地域。領地 3 ところ。場所。「異 境」4場合。めぐりあわせ。地位。「境遇」龺ありさま。 様子。「心境」

「景」：〕1ひかり、ひざし、日光。2あきらか (明)。 (3けしき。ながめ。「勝景」4ありさま。様子。おもむ

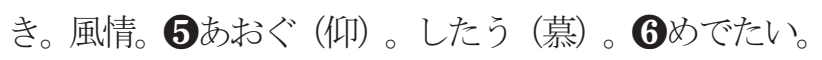

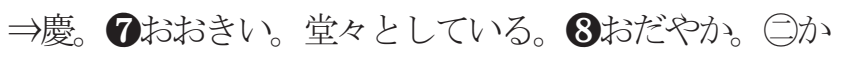
げ。光により生ずるかげ。 $\Rightarrow$ 影。（『新漢語林』大修館 書店)

とあり、2 つの文字の持つ意味の違いは混同される要素 が多いとは言い難い。このことからも『佛寺志』で「境 致」と同じ意味で「景致」という単語を使用していたと 断言するのは難しいのではないかと考える。

\section{6. 中国南宋五山寺院の「境致」についての中国と日本 の史料比較}

以上の分析から、中国の禅宗寺院について書かれた 中国語の史料には、日本で書かれた禅宗封完についての 史料とは異なり、「境致」或いは「十境」詩についての 記述が殆じ残されていないということが明らかになった。 しかし日本における「境致」選定や「十境」詩の作成は、 中国（特に南宋）の禅宗郝完の風習を取り入れたことで 日本に定着、広まったと考えられている。玉村竹二校訂 の『扶桑五山記』解説には「本書の大略の性格は題名の 通り、日本の京都・鎌倉の五山の住持歴代や、境致（境 内の目ぼしい建築や山水木石)諸塔頭・寮舎などを記し、 さらにこれに付随して、中國の五山・十刹・甲刹の開山・ 住持歴代・境致、日本の十刹・諸山の一覧、五山・十刹

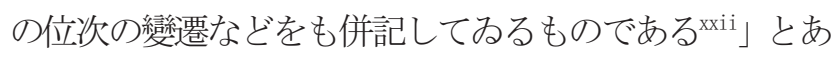
り、『扶桑五山記』に中国禅宗封院の「境致」が記載さ れていると説明されている。

『扶桑五山記』は江戸時代中期の享保七〜八年 (1722 23) の間に作成された写本で、五巻五冊からなっ ている。第一巻には「大宋國諸寺次位」と題して、中国 の五山・十刹・甲刹の所在地・住持次位と共に、境致と 考えられるものが挙げられている（ただし、これらは第 二巻の日本五山封院の場合とは異なり、「境致」と記載 された項目にまとめられているわけではない)。第二巻 は、前半には日本の五山・十刹の次位の変遷、そして諸 山の所在国・開山が記載されている。後半は、京都・鎌
倉の五山の仏殿上梁銘・境致・塔頭・住持次位の記載が はじまり、その第一位南禅寺についてまでが収録されて いる。そして第三巻以下に、南禅寺以外の京都・鎌倉五 山封完について収録されている。ただ「境致」について は、日本の五山封完の中にも記載のない封完が存在し、 反対に十刹・諸山の寺院に関しては、殆どの寺院で記載 がない中で幾つかの封完には「境致」という項目が設け られて記載されていた。日本の寺院の中で「境致」の記 載が明確であるのは、京都・鎌倉の五山封完のうち、京 都の萬寿寺と鎌倉の浄妙寺を除く 9 寺（ただし萬寿寺に は東漸和尚作の「萬壽十境偈」の記載がある）と、十刹 の大慈寺、諸山の三河州光音禅寺、大隈州正興禅寺、薩 摩州廣濟禅寺、豊後州大智寺の五寺であった。

また『扶桑五山記』と同種の「禅刹記」に『和漢禅刹 次第』があるが、これも『扶桑五山記』と同様に中国五 山封完の所在地・開山・住持歴代（元代末期頃迄）・境 致（『扶桑五山記』同様「境致」の語は記載されていな い）と十刹・甲刹の所在地・開山・境致を挙げ、さらに、 京都と鎌倉の五山・十刹の次位の変遷と諸山の一覧及び その所在地・開山・境致が挙げられており、その内容は 殆ど変らない。

ここに挙げた文献史料では、中国禅宗封完についての 記述で、中国で編纂された『中國佛寺志』と日本で編纂 された『扶桑五山記』や『和漢禅刹次第』といった「禪 刹記xxiii」における「境致」の記述に違いがみられた。そ もそも『中國佛寺志』においては、「境致」の記述は見 つからず、「十境」詩も阿育王寺の「次十境韻」のみで あった。また日本の「禅刹記」では、京都・鎌倉の五山 郝完や十刹・諸山の幾つかに「境致」の記載があったが、 中国五山封完については、境致に該当すると考えられる 題が「境致」とは明記されずに列挙してあるだけであっ た。

以上のことから、中国禅宗郝完では、「境致」という 語が一般的に使用されていたわけではなかったというこ とが考えられる。そこで『中國佛寺志』に記載されてい た「複数にまとまった題詩 (主に10 題でまとめられてい るもの）」の題と『扶桑五山記』や『和漢禅刹次第』に 記載されている「境致」と考えられる題をそれぞれの寺 院毎に比較、類別することで、中国と日本の題がそれぞ れ持つ特徽や共通性が明らかになると考えた。 


\section{（1）萬寿寺}

中国：「掲石 (嚴)」「凌霄 (閣・庵)」「含暉亭」「靈 雞塚」(4)

「堆珠峰」「大人峰」「鵬博峰」「宴坐峰」「朝陽 峰」(5)

日本：「清涼法海」（山門）「龍井（一穴）」「天下徑 山」（総門）「五髺峯」「龍淵室」（方丈）「淨髪閣」

「不動耑」「不動軒」（方丈、法堂以方丈兼）「凌霄峯」 「凌霄閣」「含暉亭」「御愛峯」「喝石嚴」「楞伽室」 「流止亭」「福地」「靈貕鳥塚」「鉢孟峯」「碁盤石」「萬 年正續院」（無隼塔）（20）（『径山志』と共通寸る題 には下線）

萬寿寺については、『扶桑五山記』には「境致」と考 えられる 20 種類の題の記載があった。『中國佛寺志』に 記載されていた題詩のうち、『扶桑五山記』に挙げられ ている題と共通しているものは 4 種類あったが、いずれ も単独で詠まれた詩と考えられる。

また『中國佛寺志』に収録されていた題詩の中には、 同一作者によって「峰」に対して詠まれた五種類の題詩 が収録されていた。これらは、五言古詩（六句）で詠ま れた「堆珠峰」「大人峰」「鵬博峰」「宴坐峰」「朝陽 峰」の五題であるが、どれも『扶桑五山記』の題には含 まれていない。しかし『扶桑五山記』の題の中にも「五 䯽峯」「凌霄峯」「御愛峯」「鉢盂峯」と、四種類の「峯」 が含まれており、「峰」や「峯」が題詩の重要な主題の 一つであったことが伺える。

中国 :「堆珠峰」「大人峰」「鵬博峰」「宴坐峰」「朝 陽峰」

日本：「五䯽峯」「凌霄峯」「御愛峯」「鉢孟峯」

\section{（2）霊隠寺}

中国：「本寺（霊隠寺）」「冷泉亭」「飛来峰」「曲水 亭」「龍泓洞」「蓮華石」「猿呼洞」「北高峰（塔）」

「九里松」「合澗橋」「石門澗」「霊隠浦」「葛塢」「蓞 光菴」「西菴」「臥犀泉」「青林洞」「白沙泉」「翻經 臺」「蓮花峰」「鍊丹井」「水臺盤」「翻㹵臺」「葛洪 井」「連䕾棧」「飯猿臺」「夢謝亭」「理公嚴」「題名 塔」(29)
日本：「蜚來峯」「冷泉亭」「猿呼洞（白猿洞）」「北 高峯」「合澗橋」「九里松徑」「直指堂」「石蓮峯」「壑 雷亭」「熟嶺」「蓮峯堂」「梅檀林」（12）（『霊隠寺 志』と共通寸る題には下線）

霊隠寺では『中國佛寺志』に記載されていた 29 種の題 のうちの 6 種類が『扶桑五山記』と共通していた。『扶 桑五山記』には 12 種類の題が記載されていたので、『扶 桑五山記』に記載されていた題の丁度半数が『中國佛寺 志』にも記載されていたことになる。共通する 6 種類は 「峯」「亭」「洞」「橋」「松（徑）」で、建造物と自 然物が混在しているが、その他の題と比較して目立った 特徴があるわけではない。

\section{（3）天童寺}

中国：「太白峰」「太白庵」「玲瓏嚴」「響石」「神龍 霐」「虎跑泉」「佛蹟石」「臨雲閣」「春楽軒」「宿鴽 亭」「太白山」「蒙堂」（12）（舒鲁の題詩 12 題、『扶 桑五山記』と共通寸る題はには下線）

日本：「五鳳樓」（千仏閣）「光明藏」「九峯」「龍潭」 「玲瓏踹」「雙沼」「宿鷺亭」「清關」「萬松關」「萬 工池」「登閣」「妙高基」「翠鎖亭」「門外二十里松徑」 「虎跑泉」「太白禪居」（16）

天童寺では『中國佛寺志』記載されていた舒亶の題詩 12 種類のうち 3 種類が『扶桑五山記』の題と共通してい た。『扶桑五山記』には 16 種類の題が記載されていたの で、そのうちの 13 種類が『中國佛寺志』には記載のない 題である。反対に、『南遊集』に収録されている別源円 旨の「和雲外和尚天童十境韻」の 10 題は全て『扶桑五山 記』の 16 種類の中に含まれていた（「萬松關」「翠鎖亭」

「宿鷺亭」「清關」「萬工池」「登閣」「玲瓏嚴」「虎 跑泉」「龍潭」「太白禪居」）。このことから、中国で 中国人によって詠まれた題詩と日本人によって書かれた 書物に収録されている題・題詩では、かなりの違いがみ られるということがわかる。

\section{(4) 浄慈寺}

中国：(0)

日本：「南屏山」(南屏峯）「慧月山」「南高峰」「六 
和塔」（后山）「枯木堂」（僧堂）「宗鏡堂」（法堂） 「六橋」「西湖」「千峯閣」「羅漢堂」「正徧知閣」「霜 花繁」（12）

浄慈寺では『中國佛寺志』には「境致」系の題詩が収 録されていなかったことから、『扶桑五山記』など日本 で編纂された史料にしか「境致」の記載は見られない。

\section{（5）阿育王寺}

中国：「舎利塔」「望海亭」「無畏堂」「淵靈廟」「玉 几峰」「金沙井」「仙書岩」「佛石」「七沸潭」「大權 洞」「承恩閣」「涌現覀」「妙喜泉」「金沙池」「佛跡 峯」「七沸石」「袈裟衣」「名月臺」「石屏峯」「靈鰻 井」「供奉泉」「育王塔」「八角殿」「晉年札」「重臺 蓮」「佛跡岩」「宸奎閣」「放光松」「赤董峰」「佛蹟 亭」「鬼谷祠」「袈裟石」（31）（『扶桑五山記』と完 全または部分的に一致しているものには下線)

日本：「玉几峯」「玉几亭」「無畏堂」「妙喜泉」「鄮 峰」「舎利道場（妙勝之殿）」「靈鰻池」

阿育王寺では『中國佛寺志』に記載されていた 31 種類 の題のうち『扶桑五山記』に記載されていたと 7 種類の 題と完全に一致していたのは 3 種類だけであった。『阿 育王寺志』には比較的多くのまとまった題詩が収録され ていたが、それぞれの題は共通していないものも多く、 題詩は合計で 31 種類にも上った。それにもかかわらず 『扶桑五山記』の 7 種類の題のうち 3 種類しか共通して いないのは決して多いとは言えない。ただ、完全には一 致していないが共通の題と考えられるものが 2 種類あつ た（「舎利塔」「靈鰻井」）。反対に、7 種類のうちで 共通ではなかった題は「玉几亭」と「鄮峰」の2 種類だ けであった。

\section{（6）小結}

『中國佛寺志』の五山寺院の中で、一定数でまとめら れた題詩が収録されていたのは、霊隠寺・天童寺・阿育 王寺の 3 寺であったが、いずれの例をみても『扶桑五山 記』や『和漢禅刹次第』といった日本で編纂された史料 に記載されていた「境致」と考えられる題と完全に一致 しているものはなかった。
はじめに霊隠寺では、 5 種類のまとまった題詩が収録 されていたが、それぞれが全く異なった題を含んでいる。 これは、「㵒湘八景」詩に見られるような特定の題が定 着していたというよりは、数ある景観の中から作者が自 らの好みで選択し、まとめたものであると推測される。 題として選ばれていた景観は合計で 29 種類あったが、そ の中で『扶桑五山記』に収録されていたものは 6 種類し かない。わかりやすい例として挙げられるものに、「霊 隠十詠」と「霊隠十景」といら題詩 2 種類がある。これ らはいずれも 10 題のまとまった題詩を集めたものだが、 この 2 種類の題詩でそれぞれ選ばれている題が共通して いるのは「猿呼洞」「蓮花峰」「龍泓洞」の 3 種類だけ であった。また、この 2 種類の題詩それぞれの『扶桑五 山記』（「境致」として挙げられているのは 12 種類）と の比較をみると、「霊隠十詠」では「泠泉亭」「飛来峰」 「猿呼洞」の 3 種類が共通しており、他に「高峰塔」が 類似している。また「霊隠十景」の方は、「猿呼洞」と 「合澗橋」の合計 2 題が共通していることがわかった。 これに対して『扶桑五山記』に「境致」として挙げられ ていたもので「霊隠十詠」と「霊隠十景」には含まれて いなかった題は「北高峯」「九里松徑」「直指堂」「石 蓮峯」「壑雷亭」「熟嶺」「蓮峯堂」「饰檀林」の 8 種 類（ただし「北高峯」は類似の題有り）で、中でも「直 指堂」と「梅檀林」は、単独の詩詠にも詠まれてはいな かった。

次に天童寺では、『天童寺志』にはまとまった形での 收録はされていなかったが、舒亶によって詠まれた 10 種類の題詩が収録されていた。これらの題詩は、舒亶の 『乾道四明図経』の中では「天童十題」としてまとまっ た形で収録されている。この題の中で『扶桑五山記』(「境 致」として挙げられているのは 16 種類）と共通している のは「玲瓏餀」「虎跑泉」「宿鷺亭」「太白庵」（ただ し『扶桑五山記』での記述は「太白禪居」）の 4 種類だ けであった。これに対して『扶桑五山記』に挙げられて いた題で「天童十題」に含まれていなかったものは「五 鳳樓」「光明藏」「九峯」「龍潭」「雙沼」「清關」「萬 松關」「萬工池」「登閣」「妙高基」「翠鎖亭」「門外 二十里松徑」の 12 種類であった。

最後に阿育王寺では、5 種類のまとまった題詩が収録 されていたが（「阿育王四景」「育王山十詠」「和育王 
十二題」「次十境韻・次十景韻」及び、釋畹荃によって 詠まれた 10 首）、この 5 種類の中で『扶桑五山記』（「境 致として挙げられているのは7 種類」と完全に一致して いるものはなかった。「阿育王四景」では「舎利塔」（た だし『扶桑五山記』では「舎利道場」）と「無畏堂」と 4 種類中の 2 種類、「和育王十二題」では「靈鰻井」（た だし『扶桑五山記』では「靈鰻池」）と 12 種類中 1 種類 しか共通していなかった。また 10 首で一まとまりになっ ている題詩では、「育王山十詠」で「舎利塔」（ただし 『扶桑五山記』では「舎利道場」）と「玉几峰」の 2 種 類、「次十境韻・次十景韻」では「舎利塔」「妙喜泉」 「玉几峯」の 3 種類、そして釋畹荃の 10 首では「玉几峰」 と「妙喜泉」の 2 種類だけであった。それに対して『扶 桑五山記』に挙げられた上記の 5 種類のまとまった題詩 のいずれにも含まれていなかったのは「玉几亭」「質峰」 の 2 種類だけであった。

\section{7. おわりに}

日本では鎌倉時代から禅宗郝完を中心、そして室町 時代になると武家や貴族の邸宅においても「境致」選定 や、それに伴った「十境」詩を作成することが盛んにな っていった。この習慣は、日本における禅宗の五山制度 が南宋五山に倣って導入された経緯から、制度に付随す る形で中国から日本にもたらされたと考えられている。 例えば関口欣也はその著書で、日本の禅宗封完が五山制 度を取り入れた時に制度の一環として境致の概念も導入 されたとし、鎌倉五山封完に見られる自然景観と建築群 および人工的環境形成の総合美が、中国宋代の禅宗寺院 における「境致」の概念に因るものであると述べている xxiv 。

確かに、『五山文学』に残る漢詩の様式・形式を見る と、中国の禅僧達が詠んでいた詩偈の影響を強く受けて いることは間違いない。そのため本論文では、「境致」 選定や「十境」詩の作成の習慣がどこでどのようにはじ まったのかを明らかにするために、中国の文献史料から 「十境」詩を探し出すことを試みた。中国宋代の禅宗寺 院についての史料はそれほど多いとは言えず、中国禅宗 封完において「境致」の選定が慣習的に行われていたと いう確かな文献史料は見つからなかった。本論文で使用 した『中國佛寺志』は、明代から清代に数多く編纂され
た中国の地方誌を扱う文献史料の一つである。その主な 内容は寺院の歷史沿革、所在地や地理環境、伽藍建築、 高僧伝、法語や詩偈、法脈、伝承、感応事跡、風俗など である。

この史料から、中国の五山郝完をはじめとする禅宗寺 院で詠まれた「一定数にまとまめられた題詩」を探し出 し分析した結果は上述の通りである。最初に、対象を南 宋五山寺院の五寺だけに絞り、『径山志』『武林靈隠寺 志』『雲林寺志』『天童寺志』『勅建浄慈寺志』『明州 阿育王山志』『明州阿育王山續志』の中に収録されてい る「一定数にまとめられた題詩」を拾い出した。その上 でそれらの題詩の題を分類し、『扶桑五山記』に記載さ れている南宋五山寺院の「境致」と考えられる題と比較 した。

次に、五山封完以外の寺院では、「境致」や「十境」 の記載がどの程度確認できるのか、或いは「景」「詠」

「題」などとの併記がみられるのかを確認するために、 先程と同様に『中國仏寺志彙刊』の五山郝完以外の全て の巻を史料として、「境」「景」「詠」「題」などの題 詩の拾い出しを行い、箇条書き形式でまとめて、五山寺 院の場合と同様の分析を行った。その結果、中国語の文 献では一定数にまとめられた題詩は頻繁に見られるにも かかわらず、それらに使用される名称は「景」や「詠」 であり、「境致」や「十境」といら語が極めて稀にしか 使用されていないことが明らかとなった。以上のことか ら「詠」、「景」、「境」の 3 文字が混同されや寸い文 字であるかを検証した。例えば『阿育王寺志』に収録さ れていた 10 首の題詩:「十詠」と、その次韻詩である「十 境」、「十景」に見られるように、「詠」、「景」、「境」 は同じような意味合いを持ち、混同して使用されたと考 えることが可能かを検証することとした。そのため「詠」

「景」「境」の 3 字は、音や意味から混同しや寸い文字 であるのかを検証した。

以上のことを検証した結果、中国禅宗封完では、「境 致」という語が一般的に使用されていたわけではなかっ たということが考えられた。そこで最後に、『中國佛寺 志』に記載されていた「複数にまとまった題詩（主に10 題でまとめられているもの)」の題と『扶桑五山記』や 『和漢禅刹次第』に記載されている「境致」と考えられ る題を、五山封完の資料に絞って比較、類別し、中国と 
日本の題がそれぞれ持つ特徵や共通性を明確にしようと 試みた。

以上の結果、『中國佛寺志』の史料からは、「境致」 や「十境」詩はほとんど見つけることができなかった。 唯一記載のあった『明州阿育王山續志』の「次十境韻」 という次韻詩についても、その 10 首の題のうちで『扶桑 五山記』に挙げられていた 7 題と共通していたのは 3 首 だけであった。『中國佛寺志』には「境致」以外の題詩 は数多く収録されており、中国禅宗郝完において、赦 とその周辺の景観に対して佳名を付けて詩を詠むという 習慣が一般的であったことは確かである。それにもかか わらず、「境致」や「十境」という語彙を使用している のは全体を通して一例だけであった。それは、このよう な形式の題詩を作成する時に「境致」や「十境」という 概念で景観を捉えるということが、我々が考えているほ ど普及していたわけではなかったという理由からくるの ではないだろうか。

上述したように、日本で編纂された『扶桑五山記』や 『和漢禅刹次第』に記載されている、「中国禅宗封完の 境致」と考えられている題について、『中國佛寺志彙刊』 の内容とは一致していないということがわかった。『中 國佛寺志彙刊』の各寺院志には「境致」という語彙が使 用されている例がないことや、さらに「境致」と同意語 として使用されていると推測できるような語彙も確認で きなかった。また、「十境」詩については全巻中で唯一 の例を『明州阿育王山續志』に確認したが、推測できる 成立年代は、日本の禅宗郝完で「十境」詩の作成が既に 一般化した後であることが明らかになった。このため、 『扶桑五山記』や『和漢禅刹次第』といった「禪刹記」 系史料の、南宋五山封完の項に記載されている「境致」 と考えられる題が、どのような経緯を経て記述されたも のであるのかが明確にできない。またはそれ以前に、日 本の禅宗寺院が中国から取り入れたと考えられている 「境致」選定と「十境」詩詠が、本当に中国禅宗郝完で も行われていたのかといらことについても、現段階にお いて確信を持つことができない。またそうであるならば、 日本の禅宗郝完における「境致」選定の定着と普及につ いては、中国の南宋五山制度を導入した時に同時に輸入 された概念という今までの解説だけでは説明が付かず、 その起源をより明確にする方法も今後検討していかねば
ならない。本論文を作成するために中国の文献史料をこ とごとく調べたわけではないので、現時点で「中国禅宗 赦には「境致」が存在しない」と断定することはでき ない。しかし「仏寺志」と銘打たれた史料に記載される 内容は、それ以外の文献と比較して、仏教寺院について の記述がより豊富であろうと想像できるので、その史料 の中に確認できなかったということは留意すべき点では ないかと考える。

\section{謝辞}

本論文は、京都造形芸術大学博士課程に於いて仲隆裕 教授の指導の下に作成しました。ここに御礼申し上げま す。

i 田島柏堂 1981 「天童山十境」と禅語散策 - 「拜登」・ 「警策」考 -」『禅研究所紀要』第 11 号、愛知学院大 学禅研究所、108 頁

ii 同上、 111 頁

iii 同上、112 頁

iv 関口欣也 1982 「中国江南の大禅院と南宋五山」『仏 教芸術』144 号、毎日新聞社、38 頁

$\mathrm{v}$ 同上、38 頁

vi 関口欣也 1991 「中世五山伽藍の源流と展開」『新編 名宝日本の美術 第 15 巻 五山と禅院』小学館、 124 頁

vii 同上、137 頁

viii 蔡敦達 2001「日本の禅院における中国的要素の摂 取:十境を中心として」『国際日本文化研究センター紀 要23』、15 頁

ix 同上、17頁

$\mathrm{x}$ 同上、18頁

xi 玉村竹二 2002 「禅院の境致一特に楼閣・廊橋について 一」横山正編『叢書 禅と日本文化』第五巻 禅と建 築・庭園、ペリカン社、78 頁

xii 明文書局編輯部編『霊隠寺志』巻八、詩詠、五言古、 509 頁

xiii 明文書局編輯部編『霊隠寺志』巻五下、歴代人物、 274 頁

xiv 中華電子佛典協會編、邓新纂續藏經 Vol.72、No.1431 『雲外和尚語録』、17 頁

$x v$ 明文書局編輯部編『勅建浄慈寺志』巻首二、 87 頁 xvi 同上、 88 頁 xvii 同上、 88 頁 xviii 明文書局編輯部編『明州阿育王山續志』巻六、876 頁

xix 明文書局編輯部編『勅建弘慈廣濟寺新志』6-24 頁 
xx 宋釋徳洪撰、宋釋覺慈輯 1664『石門文字禅 三、四』 田原仁左衞門刊、29 頁

xxi 明文書局編輯部編『䨋隠寺志』巻七、疏、436 頁 xxii 玉村竹二校『扶桑五山記』、1頁

xxiii 同上、1頁

xxiv 関口欣也 1991 「中世五山伽藍の源流と展開」『新編 名宝日本の美術 第 15 巻 五山と禅院』、小学館、 137 頁、 166 頁

参考文献

1. 田島柏堂 1981 「天童山十境」と禅語散策 - 「拜登」・ 「警策」考 -」『禅研究所紀要』第 11 号、愛知学院大 学禅研究所

2. 関口欣也 1982 「中国江南の大禅院と南宋五山」『仏 教芸術』144 号、毎日新聞社

3. 関口欣也 1991 「中世五山伽藍の源流と展開」『新編 名宝日本の美術 第 15 巻 五山と禅院』小学館

4. 蔡敦達 2001「日本の禅院における中国的要素の捸 取：十境を中心として」『国際日本文化研究センター 紀要23』国際日本文化センター

5. 玉村竹二校 1961 『扶桑五山記』鎌倉市教育委員会

6.玉村竹二 2002 「禅院の境致一特に楼閣・廊橋について一」 横山正編『叢書 禅と日本文化』第五巻 禅と建築 庭園、ペリカン社 